\title{
A Positive Psychological Theory of Judging in Hindsight
}

\author{
Jeffrey J. Rachlinski
}

Nothing is so easy as to be wise after the event. ${ }^{1}$

Everyone is familiar with the feeling that they "knew-it-allalong." Events, especially tragedies, often feel as if they were predictable. Folk wisdom admonishes us to distrust this sensation. We all know that hindsight vision is "20/20" and that "Monday morning quarterbacking" exaggerates one's ability to know the future. Learning how the story ends makes the outcome seem inevitable and predictable, thereby distorting our perception of what could have been predicted. Despite this well-known obstacle to assessing the predictability of events accurately, the law constantly requires courts to make such assessments. Numerous legal judgments, from determining whether a tort defendant failed to take reasonable care to whether a corporate officer committed securities fraud by knowingly making false statements, require that a judge or jury ignore what they have learned in hindsight. If the folk wisdom is correct, these judgments should be distrusted. Our legal system apparently relies on faulty judgments.

Research by cognitive psychologists supports the folk admonition against trusting judgments made in hindsight. Beginning with the work of Baruch Fischhoff, psychologists have demonstrated repeatedly that people overstate the predictability of past events ${ }^{2}$ - a phenomenon that psychologists have termed the "hindsight bias." Fischhoff described the bias as follows:

$\dagger$ Associate Professor, Cornell Law School. B.A., The Johns Hopkins University, 1988; M.A. (Psychology), The Johns Hopkins University, 1988; J.D., Stanford University, 1993; Ph.D. (Psychology), Stanford University, 1994. I thank the participants in workshops at the University of Illinois School of Law, Cornell Law School, and the Conference on Organizational Design, Behavioral Economics, and Law at Stanford Law School, for their input and comments on the ideas presented in this Article. I also thank Kevin Clermont, Neal Feigenson, Chris Guthrie, Reid Hastie, Jim Henderson, Mark Kelman, Russell Korobkin, Dale Nance, Phil Peters, Stewart Schwab, John Siliciano, and Thomas Ulen for additional comments. Discussions with several students, especially Ana Acena, David Eddy, Matt Kelman, Haeryung Shin, Donald Stepka, Margaret Wang, and Conrad Wolan, also added valuable insights.

' Cornman $v$ The Eastern Counties Railway Co, 157 Eng Rep 1050, 1052 (Exch 1859).

2 See Baruch Fischhoff, Hindsight $\neq$ Foresight: The Effect of Outcome Knowledge on Judgment Under Uncertainty, $1 \mathrm{~J}$ Exp Psych 288 (1975) (first describing the effect). For 
In hindsight, people consistently exaggerate what could have been anticipated in foresight. They not only tend to view what has happened as having been inevitable but also to view it as having appeared 'relatively inevitable' before it happened. People believe that others should have been able to anticipate events much better than was actually the case. ${ }^{3}$

The hindsight bias clearly has implications for the legal system. Consider, for example, the dilemma of a defendant who, despite taking reasonable care, has caused an accident and has been sued. The defendant's level of care will be reviewed by a judge or jury who already knows that it proved inadequate to avoid the plaintiff's injury. Consequently, the defendant's level of care will seem less reasonable in hindsight than it did in foresight. ${ }^{4}$ Reasonableness must be determined from the perspective of the defendant at the time that the precautions were taken, but the hindsight bias ensures that subsequent events will influence that determination. The law relies on a process that assigns liability in a biased manner.

So why does the law tolerate the presence of the hindsight bias? The hindsight bias is well-understood, and the courts encounter it on a daily basis. Is it possible that the legal system deliberately relies upon faulty judgments? The potential consequences of the hindsight bias make this question even more troublesome. The bias, in general, makes defendants appear more culpable than they really are. ${ }^{5}$ The bias can cause judges and juries to find liable even those defendants who attempted to avoid negligence by undertaking all reasonable precautions in foresight. Not only does this seem unjust, but it also might have adverse economic consequences. Any potential defendant who is aware of the implications of the hindsight bias might try to avoid liability by taking an excess of precautions. The hindsight bias thus suggests a problem with the law and economics of negli-

reviews of research on the hindsight bias, see Jay J.J. Christensen-Szalanski and Cynthia Fobian Willham, The Hindsight Bias: A Meta-analysis, 48 Org Beh \& Human Decision Processes 147, 147-48 (1991); Scott A. Hawkins and Reid Hastie, Hindsight: Biased Judgments of Past Events After the Outcomes Are Known, 107 Psych Bull 311, 312 (1990).

3 Baruch Fischhoff, For Those Condemned to Study the Past: Heuristics and Biases in Hindsight, in Daniel Kahneman, Paul Slovic, and Amos Tversky, eds, Judgment under uncertainty: Heuristics and biases 335, 341 (Cambridge 1982) (offering a thorough analysis of potential causes of the bias).

4 See Kim A. Kamin and Jeffrey J. Rachlinski, Ex Post $\neq E x$ Ante: Determining Liability in Hindsight, $19 \mathrm{~L} \&$ Human Beh 89, 101 (1995) (studying what effect the bias has on a "courtroom" liability determination).

- The bias also might affect a factfinder's judgment of a plaintiff's actions. See Part II.C. 
gence. If, as many law and economics scholars posit, the common law evolves towards efficiency, ${ }^{6}$ then why does it tolerate biased judgments that create inefficiency? The puzzle goes beyond economics, however. Liability judged in hindsight penalizes people who endeavor to comply with what the law requires of them. The law seems to have settled upon a method of determining liability that is neither efficient nor fair.

In fact, the law is not blind to the influence of the hindsight bias. Many judicial opinions explicitly recognize the prejudicial aspects of judging in hindsight, ${ }^{7}$ but the influence of the hindsight bias is difficult to avoid. The bias is caused by a deeply ingrained cognitive process, as well as significant motivational forces. Consequently, attempts to restructure decisions made in hindsight so as to avoid the bias have all failed to eliminate its influence. This conclusion suggests that a generic, one-size-fits-all remedy for 20/20 judgment in hindsight is unlikely to be available to the legal system. Even though courts recognize the presence of the bias, a solution to it might remain elusive.

Furthermore, there might not be an overwhelming need to correct for the hindsight bias. The impact of the bias on both efficiency and fairness is less destructive than it seems at first glance. If the bias induces judges and juries to hold liable defendants who actually took reasonable care, then it converts a negligence rule into a rule of strict liability. The situation is slightly more complicated than this, as defendants can probably still avoid liability altogether by taking far more precautions than reasonable care requires, but the resemblance is close. Although strict liability and negligence do have different economic consequences, strict liability does not create incentives for potential defendants to undertake an excess of precautions. Thus, the hindsight bias does not necessarily have adverse economic consequences. As to fairness, although adopting a negligence rule that nevertheless holds people strictly liable seems unjust, the injustice is hard to spot in an individual case. The judge, jury, plaintiff, and even the defendant view the events after the fact, and so holding a defendant liable may seem like the right result. In fact, a correction for the hindsight bias might seem unfair to the plain-

6 See Richard A. Posner, Economic Analysis of Law 559-60 (Little, Brown 4th ed 1992); John C. Goodman, An Economic Theory of the Evolution of Common Law, $7 \mathrm{~J}$ Legal Stud 393, 394 (1978); George L. Priest, The Common Law Process and the Selection of Efficient Rules, 6 J Legal Stud 65, 65 (1977); Paul H. Rubin, Why is the Common Law Efficient? 6 J Legal Stud 51, 53 (1977). See generally Jack Hirshleifer, ed, Evolutionary Models in Economics and Law, 4 Research in L \& Econ 1 (1982).

7 See Part IV.B.3. 
tiff, because everyone in the courtroom believes that the defendant was actually negligent.

Despite calls for reforms to eliminate the influence of the hindsight bias, ${ }^{8}$ courts have already done a remarkable job of adapting to the limitations of human judgment in hindsight. They have avoided adopting generic solutions that psychological research predicts would be unsuccessful. Instead, the courts have developed rules that take advantage of specific opportunities to avoid the bias. For example, when a reliable ex ante assessment of reasonable care is available, such as custom in medical malpractice, courts rely on it rather than their own independent assessment of reasonable care. Rules that avoid the more pernicious aspects of the bias have also developed: rules such as the inadmissibility of subsequent remedial measures as evidence of negligence. ${ }^{9}$

In many circumstances, however, no mechanism to avoid or reduce the influence of the hindsight bias is available and the law must pursue some second-best course of action. It must tolerate biased assessments of liability or create some form of immunity for potential defendants. For example, in corporate law, the business judgment rule protects corporate officers and directors from liability for negligent business decisions because, in part, of the tendency for adverse outcomes to seem inevitable. There is no such immunity for ordinary defendants in negligence, who must tolerate biased assessments of liability. Both rules are second best to using accurate assessments of negligence in hindsight. The business judgment rule leaves shareholders subject to the negligence of corporate managers. The tort system leaves defendants subject to the overattributions of fault that hindsight produces, leading to unfairness and possibly creating inefficient incentives. The differences between the two areas of law can be explained by the underlying differences in the activities combined with an understanding of the hindsight bias. ${ }^{10}$ Because the bias converts negligence into a kind of strict liability, liability for negligence would exacerbate corporate managers' tendency to be more cautious than shareholders want. The analysis in this Article shows that this biased assessment of liability does not have such a pernicious impact on the behavior of other types of professionals.

8 See, for example, Hal R. Arkes and Cindy A. Schipani, Medical Malpractice v. the Business Judgment Rule: Differences in Hindsight Bias, 73 Or L Rev 587, 630 (1994) (arguing for a change in medical malpractice rules in order to eliminate the hindsight bias).

- See text accompanying notes 201-06.

${ }^{10}$ See Arkes and Schipani, 73 Or L Rev at 621-29. 
Judicial opinions display a terrific understanding of the implications of a biased assessment of liability. Rules have evolved that reduce the bias's impact, and when its influence cannot be purged, sensible second-best rules have emerged. The law has adapted well to the fallibility of human judgment. As a consequence, understanding the hindsight bias is also critical to understanding the law.

This thesis represents a perspective on the nature of cognitive biases in law that differs markedly both from the law and economics and from the law and psychology traditions. Law and economics theorists tend to regard cognitive biases as phenomena that are either overstated or are weeded out by market forces. ${ }^{11}$ Law and psychology has a tradition of criticizing the legal system for ignoring the findings of modern psychology. ${ }^{12}$ In the case of the hindsight bias, neither perspective is accurate. Every piece of evidence suggests that the bias has an important effect on judgments of liability in the legal system, ${ }^{13}$ and a careful analysis suggests that the legal system already incorporates an understanding of the bias's implications.

This Article develops the thesis that the law reflects an understanding of the hindsight bias. In Part I, it describes the psychological research on judging in hindsight, with special attention to the sources and explanations for the hindsight bias. Part II discusses the application of the hindsight bias to judgments of liability and fault in the legal system and concludes that the bias has a big impact on judgments of liability. Part III analyzes the consequences of this phenomenon for the legal system. Part IV

" See, for example, Daniel S. Levy and David Friedman, The Revenge of the Redwoods?: Reconsidering Property Rights and the Economic Allocation of Natural Resources, 61 U Chi L Rev 493, 512-16 (1994) (arguing that the challenge that a cognitive bias known as the endowment effect poses to rational choice theory is overstated); Jonathan $R$. Macey, Packaged Preferences and the Institutional Transformation of Interests, $61 \mathrm{U}$ Chi L Rev $1443,1448-49$ (1994) (arguing that market forces pressure organizations to create mechanisms that avoid cognitive biases).

${ }^{12}$ See Shari Seidman Diamond, Foreword, in D.K. Kagehiro and W.S. Laufer, Handbook of Psychology and Law v, vi-vii (Springer-Verlag 1992) ("In some . . . cases, the courts have ignored, distorted, or rejected psychological findings."); Wallace D. Loh, In Quest of Brown's Promise: Social Research and Social Values in School Desegregation, 58 Wash L Rev 129, 171 (1982) (book review) (comparing the way courts use social science to "the way a drunk uses a lamppost: for support rather than illumination"); John Monahan and Laurens Walker, Social Science Research in Law: A New Paradigm, 43 Am Psych 465, 465 (1988) ("Psychologists] repeatedly complain that their research is either ignored or misconstrued."). See generally Michael J. Saks and Charles H. Baron, eds, The Use/Nonuse/Misuse of Applied Social Research in the Courts 28-56 (Abt 1980) (documenting courts' abuse of legitimate research methods).

${ }^{13}$ See Part II. 
documents the adaptations that the legal system has developed to accommodate the hindsight bias, and Part V states conclusions.

\section{PSYCHOLOGICAL RESEARCH ON JUDGING IN HINDSIGHT}

A. What Is the Hindsight Bias?

Research by cognitive psychologists has shown that the folk wisdom on hindsight is correct-past events seem more predictable than they really were. Baruch Fischhoff provided the first systematic demonstration of this phenomenon. ${ }^{14}$ In his study, Fischhoff gave undergraduate subjects a description of an unfamiliar, nineteenth century war between the British and the Nepalese Gurkhas. ${ }^{15}$ His materials consisted of a 150-word description of the conflict, including the strengths and weaknesses of each army. This description listed four possible outcomes of the conflict (British victory, Gurkha victory, stalemate with no peace settlement, and stalemate with a peace settlement). The remainder of Fischhoff's materials split into five different conditions. The materials either stated that one of the four possible outcomes had actually occurred or provided no information about the actual outcome. Subjects read the materials and then answered the following question: "In light of the information appearing in the passage, what was the probability of occurrence of each of the four possible outcomes ... [?] ${ }^{\text {116 }}$ Subjects who were told that one of the outcomes had occurred made inflated estimates of the ex ante likelihood of that outcome (as compared with subjects who were given no information about the outcome). In fact, the mean probabilities that subjects assigned to the supposed outcome of the conflict summed to 170 percent, whereas they would have summed to approximately 100 percent if knowing the outcome had not influenced the subjects. In this study, and in the replications that Fischhoff ran with other scenarios, providing subjects with an outcome increased their estimates of the likelihood of that outcome by between 6.3 and 44.0 percentage points. ${ }^{17}$

It is important to distinguish between the hindsight bias and the more ordinary process of learning from experience. In most

"Fischhoff, $1 \mathrm{~J}$ Exp Psych at 288 (cited in note 2). The literature credits Fischhoff with first identifying the bias and coining the term "hindsight bias." See Stephen J. Hoch and George F. Loewenstein, Outcome Feedback: Hindsight and Information, $15 \mathrm{~J} \mathrm{Exp}$ Psych: Learning, Memory, \& Cognition 605, 605 (1989). But an earlier article on a different subject also describes the same phenomenon. See Elaine Walster, 'Second Guessing' Important Events, 20 Human Rel 239, 244-49 (1967).

1s Fischhoff, $1 \mathrm{~J}$ Exp Psych at 289-90 (cited in note 2).

${ }^{16}$ Id at 289.

${ }^{17}$ Id at 291. 
circumstances, learning an outcome should cause people to update their estimates of an event's likelihood. ${ }^{18}$ If Fischhoff had asked his subjects to estimate the probabilities of the possible outcomes of a future conflict between the British and the Gurkhas, it would have been appropriate for the subjects to suppose that history might repeat itself. Fischhoff did not ask his subjects to predict a future event, however; he asked them to judge the predictability of past events as if they were ignorant of the known outcome. His subjects behaved as if they were supposed to learn from the outcome, even though that was not their chore.

Determining the predictability of once-future events is a somewhat unnatural undertaking, ${ }^{19}$ but Fischhoff's findings are not merely the product of his subjects' confusion. Using comparable materials, Fischhoff provided subjects with an outcome and then asked them to estimate the probability that other subjects, who were not informed of the outcome, would have assigned to each possible outcome. ${ }^{20}$ This explicitly required the subjects to try to see the world through the eyes of those who did not know how the events unfolded; however, they were unable to do so. These subjects provided the same biased assessments of what was predictable as did subjects in Fischhoff"s first study. ${ }^{21}$

Furthermore, other studies have demonstrated not only that people claim that they would have known it all along, but also that they maintain that they did, in fact, know it all along. ${ }^{22}$ Researchers asked subjects to estimate the likelihood of the outcome of some imminent event (such as an election) and then, some time after the event, asked the same subjects to remember their estimates. Although subjects in these studies often correctly recalled their initial estimates, when they erred, they tended to believe that they had assigned higher estimates to the actual outcomes than they originally did. Dozens of researchers have replicated Fischhoff's findings using both the "I would have predicted it"

13 See Hoch and Loewenstein, $15 \mathrm{~J}$ Exp Psych at 605 (cited in note 14) (discussing patterns of learning from experience).

${ }^{29}$ See Baruch Fischhoff, Debiasing, in Kahneman, Slovic, and Tversky, eds, Judgment under uncertainty 422, 428-29 (cited in note 3 ).

${ }^{20}$ Fischhoff, $1 \mathrm{~J}$ Exp Psych at 295-97 (cited in note 2).

${ }^{21}$ Id at 296-97.

${ }^{2}$ See Hawkins and Hastie, 107 Psych Bull at 314-15 (cited in note 3). One recent article, however, has argued that the hindsight bias observed in studies using this method results from a different process than the hindsight bias observed in studies using Fischhoff's original methodology. Ralph Hertwig, Gerd Gigerenzer, and Urich Hoffrage, The Reiteration Effect in Hindsight Bias, 104 Psych Rev 194, 201 (1997). 
and the "I did predict it" methods. The hindsight bias is not the unique product of an unusual research methodology. ${ }^{23}$

Researchers also have used a wide range of different materials to document the hindsight bias. Many studies in addition to Fischhoff's original work have replicated his results with historic events, including everything from Nixon's visit to China in 1972 to the riots that followed the verdict in the first Rodney King case. ${ }^{24}$ In other studies, researchers have found that subjects also rate the outcome of more ordinary events, such as whether a business would be successful, as more predictable than they are..$^{25}$

${ }^{23}$ See Christensen-Szalanski and Willham, 48 Org Beh \& Human Decision Processes at 150 (cited in note 2) (observing that, as of 1990 , there were 128 studies documenting the hindsight bias).

${ }^{24}$ See Baruch Fischhoff and Ruth Beyth, "I Knew It Would Happen": Remembered Probabilities of Once-Future Things, 13 Org Beh \& Human Performance 1, 3 (1975) (Nixon's 1972 diplomatic missions to China and Russia); Lee J. Gilbertson, et al, A Study of Hindsight Bias: The Rodney King Case in Retrospect, 74 Psych Rep 383, 384 (1994) (consequences of verdict in the first Rodney King case); Fischhoff, $1 \mathrm{~J}$ Exp Psych at 289 (cited in note 2) (near riot in Atlanta); Mark R. Leary, The Distorted Nature of Hindsight, 115 J Soc Psych 25, 27 (1981) (college football game); Donald C. Pennington, The British fireman's strike of 1977/78: An investigation of judgments in foresight and hindsight, 20 Brit J Soc Psych 89, 90-91 (1981) (a fireman's strike in Great Britain); David Wasserman, Richard O. Lempert, and Reid Hastie, Hindsight and Causality, 17 Personality \& Soc Psych Bull 30, 32 (1991) (the same British-Gurkha materials that Fischhoff used). Several studies have used elections. Mark R. Leary, Hindsight Distortion and the 1980 Presidential Election, 8 Personality \& Soc Psych Bull 257, 259-60 (1982) (1980 presidential election); Donald C. Pennington, Being Wise after the Event: an Investigation of Hindsight Bias, 1 Current Psych Res 271, 273 (1981) (British general election of 1979); Jack L. Powell, $A$ Test of the Knew-It-All-Along Effect in the 1984 Presidential and Statewide Elections, 18 J Applied Soc Psych 760, 762-63 (1988) (1984 presidential and Missouri state elections); Nicolaos E. Synodinos, Hindsight Distortion: "I knew-it-all along and I was sure about it ${ }^{\prime}, 16$ J Applied Soc Psych 107, 109-14 (1986) (1982 Hawaiian gubernatorial election).

${ }^{25}$ See Clifton E. Brown and Ira Solomon, Effects of Outcome Information on Evaluations of Managerial Decisions, 62 Acct Rev 564, 568-75 (1987) (likely success of a new business venture); Richard S. Brown, Christopher W. Williams, and Paul R. Lees-Haley, The Effects of Hindsight Bias and Causal Attribution on Human Response to Environmental Events, 24 J Applied Soc Psych 661, 664-65 (1994) (outcome knowledge effect on responses to hazardous waste disposal); Thomas A. Buchman, An Effect of Hindsight on Predicting Bankruptcy with Accounting Information, 10 Acct Org \& Soc 267, 274 (1985) (predicting a bankruptcy); Edward W. Bukszar and Terry Connolly, Hindsight Bias and Strategic Choice: Some Problems in Learning from Experience, 31 Acad Mgmt J 628, 63031 (1988) (predicting the success or failure of a new business); Colleen $\mathrm{K}$ Cannon and Vernon L. Quinsey, The Likelihood of Violent Behavior: Predictions, Postdictions, and Hindsight Bias, 27 Canadian J Beh Sci 92, 94-95 (1995) (the likelihood of a violent offender recidivating); Terry Connolly and Edward W. Bukszar, Hindsight Bias: SelfFlattery or Cognitive Error?, $3 \mathrm{~J}$ Beh Decision Making 205, 207 (1990) (predicting the success or failure of a new business); Walster, 20 Human Rel at 240 (cited in note 14) (the consequences of purchasing a house); Rami Zwick, Rik Pieters, and Hans Baumgartner, On the Practical Significance of Hindsight Bias: The Case of Expectancy-Disconfirmation Model of Consumer Satisfaction, 64 Org Beh \& Human Decision Processes 103, 105 (1995) (the expected quality of consumer products). In several studies, subjects rated the predictability of the outcome of social psychological experiments. Martin F. Davies, Reduction of 
Still other studies have demonstrated that the hindsight bias makes significant personal events, especially tragedies, seem predictable. $^{26}$

The bias is not limited to specific populations of subjects, either. Although most of the hindsight studies have relied on college undergraduates in the United States, several have used students in other countries, ${ }^{27}$ and a few have used populations other than undergraduates. ${ }^{28}$ Studies even have demonstrated that the bias influences the judgments of experts in several different

Hindsight Bias by Restoration of Foresight Perspective: Effectiveness of Foresight-Encoding and Hindsight-Retrieval Strategies, 40 Org Beh \& Human Decision Processes 50, 53 (1987); Martin F. Davies, Field-Dependence and Hindsight Bias: Output Interference in the Generation of Reasons, 27 J Res Personality 222, 278-80 (1993); Paul Slovic and Baruch Fischhoff, On the Psychology of Experimental Surprises, 3 J Exp Psych: Human Perception \& Performance 544, 545-46 (1977); Dagmar Stahlberg, et al, We Knew It All Along: Hindsight Bias in Groups, 63 Org Beh \& Human Decision Processes 46, 51-52 (1995).

${ }^{2}$ See Robert P. Agans and Leigh S. Shaffer, The Hindsight Bias: The Role of the Availability Heuristic and Perceived Risk, 15 Basic \& Applied Soc Psych 439, 444 (1994) (being the victim of a homicide or a car accident); Linda L. Carli and Jean Brown Leonard, The Effect of Hindsight on Victim Derogation, $8 \mathrm{~J}$ Soc \& Clinical Psych 331, 334-35 (1989) (likelihood of becoming the victim of a rape); Fischhoff, $1 \mathrm{~J}$ Exp Psych at 289 (cited in note 2) (outcome of treatment for psychiatric patients); William C. Goggin and Lillian M. Range, The Disadvantages of Hindsight in the Perception of Suicide, $3 \mathrm{~J}$ Soc \& Clinical Psych 232, 233 (1985) (likelihood that another will commit suicide); Nick Haslam and Nimali Jayasinghe, Negative Affect and Hindsight Bias, $8 \mathrm{~J}$ Beh Decision Making 127, 129 (1995) (predicting own score on a midterm exam); Melvin M. Mark and Steven Mellor, $E f$ fect of Self-Relevance of an Event on Hindsight Bias: The Foreseeability of a Layoff, $76 \mathrm{~J}$ Applied Psych 569, 570-71 (1991) (being laid off from work); Michelle R. Nario and Nyla R. Branscombe, Comparison Processes in Hindsight and Causal Attribution, 21 Personality \& Soc Psych Bull 1244, 1246-47 (1995) (dying in a plane crash); Donald C. Pennington, et al, Estimating the outcome of a pregnancy test: Women's judgments in foresight and hindsight, 19 Brit J Soc \& Clinical Psych 317, 318-19 (1980) (outcome of a pregnancy test); Neal J. Roese and James M. Olson, Counterfactuals, Causal Attributions, and the Hindsight Bias: A Conceptual Integration, 32 J Exp Soc Psych 197, 204-05 (1996) (someone else's score on a midterm exam).

${ }^{27}$ See Cannon and Quinsey, 27 Canadian J Beh Sci at 94 (cited in note 25) (Canada); Davies, 40 Org Beh \& Human Decision Processes at 53 (cited in note 25) (England); Davies, $27 \mathrm{~J}$ Res Personality at 224 (England); Fischhoff, $1 \mathrm{~J}$ Exp Psych at 289 (cited in note 2) (Israel); Wolfgang Hell, et al, Hindsight Bias: An Interaction of Automatic and Motivational Factors?, 16 Memory \& Cognition 533, 535 (1988) (Germany); Pennington, 1 Current Psych Res at 273 (cited in note 24) (England); Rudiger F. Pohl and Wolfgang Hell, No Reduction in Hindsight Bias After Complete Information and Repeated Testing, 67 Org Beh \& Human Decision Processes 49, 51 (1996) (Germany); Donald Sharpe and John G. Adair, Reversibility of the Hindsight Bias: Manipulation of Experimental Demands, 56 Org Beh \& Human Decision Processes 233, 236-37 (1993) (Canada); Stahlberg, et al, 63 Org Beh \& Human Decision Processes at 51 (Germany).

${ }^{25}$ See Mark and Mellor, $76 \mathrm{~J}$ Applied Pysch at 571 (cited in note 26) (union members in a Northeastern industrial area); Pennington, 1 Current Psych Res at 273 (cited in note 24) (active members of Tory and Labour Parties in England); Pennington, et al, 19 Brit J Soc \& Clinical Psych at 319 (adult women in England). 
fields. ${ }^{29}$ Two studies have shown that even state and federal judges are susceptible to the bias. ${ }^{30}$

Virtually every study on judging in hindsight has concluded that events seem more predictable than they actually are. ${ }^{31}$ The research on judging in hindsight, taken as a whole, strongly supports Fischhoff"s conclusion that "[f]inding out that an outcome has occurred increases its perceived likelihood. ${ }^{32}$ "The overwhelming verdict . . . is that the hindsight bias is a robust phenomenon that is not easily eliminated or even moderated. ${ }^{33}$

${ }^{2}$ See John C. Anderson, D. Jordan Lowe, and Philip M.J. Reckers, Evaluation of auditor decisions: Hindsight bias effects and the expectation gap, $14 \mathrm{~J}$ Econ Psych 711, 722 (1993) (professional auditors and state and federal judges); Hal R. Arkes, et al, Eliminating the Hindsight Bias, 73 J Applied Psych 305, 306 (1988) (neuropsychologists); Hal R. Arkes, et al, Hindsight Bias Among Physicians Weighing the Likelihood of Diagnoses, $66 \mathrm{~J}$ Applied Psych 252, 252-53 (1981) (medical doctors); Don E. Detmer, et al, Heuristics and Biases in Medical Decision-Making, $53 \mathrm{~J}$ Med Educ 682, 682 (1978) (university surgeons); Raanon Lipshitz and Dalya Barak, Hindsight wisdom: Outcome knowledge and the evaluation of decisions, 88 Acta Psychologica 105, 110 (1995) (officers in the Israeli Defense Force); Terence R. Mitchell and Laura S. Kalb, Effects of Outcome Knowledge and Outcome Valence on Supervisors' Evaluations, 66 J Applied Psych 604, 605 (1981) (graduate nursing students). Several studies use advanced business school students. Buchman, 10 Acct Org \& Soc at 270 (cited in note 25); Bukszar and Connolly, 31 Acad Mgmt J at 630 (cited in note 25); Connolly and Bukszar, $3 \mathrm{~J}$ Beh Decision Making at 207 (cited in note 25); Hoch and Loewenstein, $15 \mathrm{~J}$ Exp Psych at 610 (cited in note 14).

${ }^{30}$ Anderson, Lowe, and Reckers, $14 \mathrm{~J}$ Econ Psych at 722-30; Marianne M. Jennings, D. Jordan Lowe, and Philip M.J. Reckers, Outcome Foreseeability and its Effects on Judicial Decisions (unpublished manuscript on file with U Chi L Rev).

${ }^{31}$ Two studies reported a "reverse" hindsight bias. David Mazursky and Chezy Ofir, "I Could Never Have Expected It to Happen": The Reversal of the Hindsight Bias, 46 Org Beh \& Human Decision Processes 20, 25-31 (1990) (People rating low-quality consumer products mistakenly recall that their initial expectations were better than they in fact were.); Bas Verplanken and Rik G.M. Pieters, Individual Differences in Reverse Hindsight Bias: I Never Thought Something Like Chernobyl Would Happen. Did I?, 1 J Beh Decision Making 131, 140-41 (1988) (Subjects made lower estimates of the likelihood that a nuclear accident causing ten thousand or more casualties would occur in the next ten years five months after the Chernobyl nuclear accident than they did beforehand.). The interpretations of the data in these studies have been criticized, however, and, in fact, both studies probably supported the existence of the hindsight bias. See Hal R. Arkes, Commentary on the Article by Verplanken and Pieters, $1 \mathrm{~J}$ Beh Decision Making 146, 146 (1988) (concluding that since Chernobyl did not produce more than ten thousand casualties, Verplanken and Pieter's results actually support the hindsight bias); Melvin M. Mark and Steven Mellor, "We Don't Expect it Happened": On Mazursky and Ofir's (1990) Purported Reversal of the Hindsight Bias, 57 Org Beh \& Human Decision Processes 247, 249-51 (1994) (providing several alternative explanations for the results of Mazursky and Ofir). But see Bas Verplanken and Rik Pieters, A second look at hindsight, $1 \mathrm{~J}$ Beh Decision Making 147, 147 (1988) (defending the results of their earlier study). Similarly, a few studies have also reported conditions that elicited no statistically significant bias. See, for example, Agans and Shaffer, 15 Basic \& Applied Soc Psych at 445-46 (cited in note 26) (finding that the predicted likelihood of a smoker contracting lung cancer was the same for both hindsight and foresight subjects). But an occasional failure to find the bias should be expected among such a large number of studies.

${ }^{32}$ Fischhoff, $1 \mathrm{~J}$ Exp Psych at 297 (cited in note 2).

${ }^{33}$ Hoch and Loewenstein, $15 \mathrm{~J}$ Exp Psych at 606 (cited in note 14). 
Thus, across a wide variety of tasks, materials, and populations, a sizeable ${ }^{34}$ and consistent bias clouds judgments made in hindsight.

The hindsight bias also is related closely to a phenomenon known as the "outcome bias." ${ }^{35}$ This refers to the tendency to base assessments of a decision's quality on its consequences. ${ }^{36}$ Because the hindsight bias increases the perceived likelihood of a known outcome, it makes decisionmakers appear as if they used inappropriate probability estimates. The outcome, however, also has a direct influence on the perceived quality of a decision, even apart from the outcome's impact on perceived probabilities-which is evidence of an outcome bias independent of the hindsight bias. When decisions turn out badly, people assume that decisionmakers made poor choices. ${ }^{37}$

${ }^{3}$ One review estimated that in those studies that are the most relevant to the legal system, which are studies using the "would have known" methodology in unfamiliar contexts, the bias can cause as much as 27 percent of a population to change its mind in a dichotomous decision. Christensen-Szalanski and Willham, 48 Org Beh \& Human Decision Processes at 161 (cited in note 2). Factors that are relevant to a determination of liability, but that were not incorporated into this estimate, can increase the size of the effect even further. For example, negative events, which would be more typical subjects of a legal dispute than positive ones, result in a larger bias, see Brown, Williams, and Lees-Haley, $24 \mathrm{~J}$ Applied Soc Psych at 665-72 (cited in note 25); Haslam and Jayasinghe, $8 \mathrm{~J}$ Beh Decision Making at 129-36 (cited in note 26); Lipshitz and Barak, 88 Acta Psychologica at 110-15, 122 (cited in note 29); Mitchell and Kalb, $66 \mathrm{~J}$ Applied Psych at 605-09 (cited in note 29); David A. Schkade and Lynda M. Kilbourne, Expectation-Outcome Consistency and Hindsight Bias, 49 Org Beh \& Human Decision Processes 105, 111-19 (1991); Walster, $20 \mathrm{Hu}-$ man Rel at 240-48 (cited in note 14). More complex material can also increase the size of the effect. See Nario and Branscombe, 21 Personality \& Soc Psych Bull at 1248-52 (cited in note 26); Pennington, 20 Brit J Soc Pysch at 93-95 (cited in note 24); Roese and Olson, $32 \mathrm{~J}$ Exp Soc Psych at 205-18 (cited in note 26).

${ }^{3}$ See Jonathan Baron and John C. Hershey, Outcome Bias in Decision Evaluation, 54 $J$ Personality \& Soc Psych 569, 570 (1988) (describing and documenting the outcome bias).

${ }^{3}$ Many studies have found such a tendency. See, for example, Carli and Leonard, $8 \mathrm{~J}$ Soc \& Clinical Psych at 338 (cited in note 26) (People blamed a rape victim for failing to have avoided a situation that made her vulnerable to attack-even though people in foresight stated that the same situation seemed benign.); Goggin and Range, 3 J Soc \& Clinical Psych at 234-35 (cited in note 26) (People blame the family members of a suicide victim for failing to have predicted the tragedy.); Lipshitz and Barak, 88 Acta Psychologica at 110-15 (cited in note 29) (The consequences of a threatened terrorist attack heavily influenced Israeli Defense Force officer's evaluations of a military commander's response to the threat.). A series of studies have demonstrated the influence of the outcome and the hindsight biases on evaluations of accountants' decisions. Anderson, Lowe, and Reckers, $14 \mathrm{~J}$ Econ Psych at 725-27 (cited in note 29); D. Jordan Lowe and Philip M.J. Reckers, The Effects of Hindsight Bias on Jurors' Evaluations of Auditor Decisions, 25 Decision Sci 401, 413-14 (1994); Jennings, Lowe, and Reckers (unpublished manuscript) (cited in note 30).

${ }^{37}$ See Dan Zakay, The Evaluation of Managerial Decisions' Quality by Managers, 56 Acta Psychologica 49, 52 (1984) (Professional managers consider a decision's outcome to be the most important factor in evaluating the quality of a decision.). 


\section{B. Causes of the Hindsight Bias}

Why is a known outcome so difficult to ignore? Psychologists have proposed three principal theories to explain the hindsight bias. Two theories are motivational, meaning that they attribute the bias to people's needs or desires, and the third theory is cognitive, meaning that it attributes the bias to the mental strategies that people rely upon when making judgments in hindsight. First, people want to see the world as stable and predictable, and the hindsight bias is simply part of more global coping mechanisms. Second, most people want others to think of them as intelligent and perceptive, and so they exaggerate their ability to predict outcomes. Finally, the cognitive theory proposes that learning an outcome alters what people believe about the world in ways that make the known outcome seem inevitable. Other explanations have been proposed as well, but they have been rejected, ${ }^{38}$ leaving these three theories as the principal explanations for the bias. Of the three, the cognitive theory provides the best account of the hindsight bias, although motivational factors probably also influence judgments made in hindsight.

\section{Theory one: the just world theory.}

"One undoubtedly feels more secure if the world seems like an orderly and predictable place. ${ }^{339}$ This desire manifests itself in a belief called the "just world theory. ${ }^{\text {M40 }}$ Individuals who subscribe to the just world theory believe that "people usually get what they deserve ${ }^{n 41}$ People differ in their tendency to believe in a just world, but most subscribe to this belief to some degree. The hind-

${ }^{33}$ One early explanation for the bias was that the past seems more certain and hence more predictable than the future, but Fischhoff tested and rejected this hypothesis. See Baruch Fischhoff, The Effect of Temporal Setting on Likelihood Estimates, 15 Org Beh \& Human Decision Processes 180, 192-93 (1976). See also Deborah J. Mitchell, J. Edward Russo, and Nancy Pennington, Back to the Future: Temporal Perspective in the Explanation of Events, $2 \mathrm{~J}$ Beh Decision Making 25, 35 (1989) (discussing, testing, and rejecting this hypothesis). Another possible cause of the bias is that people anchor their estimates of what they would have known around certainty (100 percent probability) and adjust downward-insufficiently. Fischhoff, $1 \mathrm{~J}$ Exp Psych at 298 (cited in note 2). This hypothesis, however, fails to account for findings that indicate that the known outcome influences subjects' interpretation of the antecedent events. See Hawkins and Hastie, 107 Psych Bull at 321 (cited in note 2). The anchoring hypothesis also predicts that the size of the effect would not vary depending upon whether the subject was told an event did or did not occur; in fact, the effect is larger for occurrences than nonoccurrences. Id.

${ }^{30}$ Walster, 20 Human Rel at 239 (cited in note 14).

${ }^{40}$ See generally Melvin J. Lerner and Dale T. Miller, Just World Research and the Attribution Process: Looking Back and Ahead, 85 Psych Bull 1030 (1978) (discussing the just world theory).

"Id at 1030. 
sight bias seems closely related to the belief in a just world. If a tragedy was foreseeable, then logically, its victims can be blamed for failing to avoid it. ${ }^{42}$ Attributing the hindsight bias to the need to believe in a just world would also explain why the bias seems especially pronounced for adverse events, ${ }^{43}$ because people presumably have a greater need to control adversity than good fortune. ${ }^{44}$ Even though some research shows that there is a positive correlation between the hindsight bias and the belief in a just world, this correlation is weak. ${ }^{45}$ The need to see the world as stable and orderly fails to completely account for the hindsight bias.

\section{Theory two: impression management.}

Subjects in psychology experiments, as in most social settings, try to avoid looking foolish-a phenomenon known as "impression management. ${ }^{346}$ Consequently, subjects in the hindsight studies might be asserting that they could have predicted outcomes even if others could not as part of an effort to show the experimenter (or other subjects or themselves) that they are intelligent. Several findings, however, are inconsistent with the impression management theory. Even when subjects know that their responses are anonymous, they still exhibit a hindsight bias. ${ }^{47}$ Also, there is no correlation between the importance of the materials to the subjects and the magnitude of the bias. ${ }^{48}$ Pre-

2 See Walster, 20 Human Rel at 239 (cited in note 14).

${ }^{43}$ See Brown, Williams, and Lees-Haley, $24 \mathrm{~J}$ Applied Soc Psych at 665-72 (cited in note 25); Haslam and Jayasinghe, $8 \mathrm{~J}$ Beh Decision Making at 129-34 (cited in note 26); Lipshitz and Barak, 88 Acta Psychologica at 108, 117-23 (cited in note 29); Mitchell and Kalb, 66 J Applied Psych at 605-09 (cited in note 29); Schkade and Kilbourne, 49 Org Beh \& Human Decision Processes at 111-19 (cited in note 34); Walster, 20 Human Rel at 24048 (cited in note 14).

4 See Walster, 20 Human Rel at 239 (cited in note 14).

is See Jennifer D. Campbell and Abraham Tesser, Motivational interpretations of hindsight bias: An individual difference analysis, $51 \mathrm{~J}$ Personality 605, 613-15 (1983) (finding a marginal correlation between hindsight bias and "just deserts"); Carli and Leonard, $8 \mathrm{~J}$ Soc \& Clinical Psych at 335 (cited in note 26) (finding no appreciable relationship between the bias and the "just world theory"); Walster, 20 Human Rel at 249 (cited in note 14). If the data from Verplanken and Pieters, $1 \mathrm{~J}$ Beh Decision Making at 141 (cited in note 31), should be reinterpreted as previously described, then this study also obtained similar results.

ts See generally Barry R. Schlenker, Impression Management: The Self-Concept, Social Identity, and Interpersonal Relations (Brooks/Cole 1980) (discussing the elaborate literature on impression management).

${ }^{47}$ Connolly and Bukszar, $3 \mathrm{~J}$ Beh Decision Making at 208 (cited in note 25).

${ }^{28}$ Campbell and Tesser, $51 \mathrm{~J}$ Personality at 612-15; Leary, $115 \mathrm{~J} \mathrm{Soc} \mathrm{Psych} \mathrm{at} 28$ (cited in note 24); Leary, 8 Personality \& Soc Psych Bull at 260-61 (cited in note 24); Synodinos, $16 \mathrm{~J}$ Applied Soc Psych at 110-14 (cited in note 24). Only Mark and Mellor, 76 J Applied Psych at 569-75 (cited in note 26), found any relationship between the size of the bias and 
sumably, the more significant that the materials are to one's selfesteem, the more critical it would be to have accurately predicted the outcome. Furthermore, increasing subjects' motivation to make accurate estimates reduces, but does not eliminate, the hindsight bias. ${ }^{49}$ Finally, in studies in which subjects had to recall the estimates that they provided before they knew the outcomeeven though the subjects were aware that the experimenter had recorded their original estimates and that reporting biased recollections would only make them look foolish-they still exhibited a hindsight bias. ${ }^{50}$ Although impression management affects the size of the hindsight bias, like the belief in a just world, it does not explain all of the data. Overall, "motivational factors do not appear to play a large role" in explaining the hindsight bias. ${ }^{51}$

\section{Theory three: cognitive explanations.}

Motivational explanations thus being inadequate, the hindsight bias must be the product of the thought process that people use to make judgments in hindsight. Fischhoff"s phrase, "creeping determinism," itself describes the cognitive theory that best explains the hindsight bias. ${ }^{52}$ According to this theory, people naturally integrate an outcome and the events that preceded it into a coherent story. ${ }^{53}$ In so doing, they attribute the outcome to some of the precipitating circumstances, making these circumstances seem more significant than they appeared in foresight. ${ }^{54}$ People also downplay the importance of other antecedents that would have been likely to lead to alternative outcomes. ${ }^{55}$ For ex-

the importance of the material to the subjects.

9 See Elizabeth Creyer and William T. Ross, Jr., Hindsight Bias and Interference in Choice: The Mediating Effect of Cognitive Effort, 55 Org Beh and Human Decision Processes 61, 71-73 (1993) (finding that hindsight bias was reduced when accuracy of prediction was important); Davies, $27 J$ Res Personality at 225-32 (cited in note 25) ("[D]nstructions to work harder or to avoid hindsight bias have no impact on the magnitude of the hindsight bias."); Baruch Fischhoff, Perceived Informativeness of Facts, $3 \mathrm{~J}$ Exp Psych: Human Perception \& Performance 349, $354-56$ (1977) (finding that hindsight bias is unaffected by warnings about its effect); Hell, et al, 16 Memory \& Cognition at 537 (cited in note 27) (finding that incentive for correct recall did not reduce hindsight bias); Sharpe and Adair, 56 Org Beh \& Human Decision Processes at 238-42 (cited in note 27) (instructing students not to produce biased assessments had no impact on the hindsight bias).

${ }^{\text {so }}$ See Hawkins and Hastie, 107 Psych Bull at 312-14 (cited in note 2).

${ }^{31}$ Id at 317.

${ }^{52}$ Fischhoff, $1 \mathrm{~J}$ Exp Psych at 288 (cited in note 2). See Hawkins and Hastie, 107 Psych Bull at 322 (cited in note 2), for a full description and elaboration of this theory.

${ }^{33}$ See Fischhoff, $1 \mathrm{~J}$ Exp Psych at 297 (cited in note 2); Hawkins and Hastie, 107

Psych Bull at 322 (cited in note 2) (arguing that the process is not automatic).

${ }^{54}$ See Hawkins and Hastie, 107 Psych Bull at 321-22 (cited in note 2).

ss See id. Ignoring inconsistent information is a common problem in judgment tasks. 
ample, in Fischhoff's original study using the British-Gurkha conflict, subjects told that the British had won rated the British advantages (better weapons and training) as more relevant to the outcome than the Nepalese advantages (better motivation and familiarity with the terrain). ${ }^{56}$ These subjects probably also concluded that training and weapons are more important to a military victory under these circumstances than motivation and familiarity with the terrain, and perhaps are more significant in warfare generally. ${ }^{57}$ These subjects naturally relied upon these inferences to judge the likely outcome of the conflict. Even if people can suppress specific knowledge of the outcome, they are unable to forget the insights inferred from that outcome..$^{58}$ Consequently, the actual outcome seems more likely after it is known than beforehand.

The creeping determinism theory has other support in the literature. Materials that directly attribute the outcome to an occurrence unrelated to any of the antecedents do not produce a hindsight bias. ${ }^{59}$ For example, subjects reading the BritishGurkha conflict who were told that the Nepalese won due to a freak snow storm did not rate a Nepalese victory as more likely than subjects who were not told the outcome of the conflict. ${ }^{60}$ Creeping determinism also explains why adding more information increases the size of the bias; ${ }^{61}$ the more antecedent facts that can be integrated into an explanation for the outcome, the more inevitable it will seem. This theory also accounts for the finding that materials describing the occurrence of an event pro-

See Asher Koriat, Sarah Lichtenstein, and Baruch Fischhoff, Reasons for Confidence, $6 \mathrm{~J}$ Exp Psych: Human Learning \& Memory 107, 108 (1980) (finding that subjects remain confident in their decisions despite being confronted with conflicting information).

${ }^{56}$ Fischhoff, $1 \mathrm{~J}$ Exp Psych at 291-92, 295-97 (cited in note 2). This result has been replicated in other contexts. See Anderson, Lowe, and Reckers, $14 \mathrm{~J}$ Econ Psych at 727-30 (cited in note 29) (Subjects who learned that a company subsequently went bankrupt rated "accounting red flags" as more important than subjects told that the company did well.); Lowe and Reckers, 25 Decision Sci at 413 (cited in note 36) (Subjects told that an investment went badly rated negative signs as more important and positive signs as less important than subjects told that the investment went well.).

${ }^{57}$ See Hawkins and Hastie, 107 Psych Bull at 322 (cited in note 2).

s See generally Marcia K. Johnson, Shahin Hashtroudi, and D. Stephen Lindsay, Source Monitoring, 114 Psych Bull 3 (1993) (discussing the difficulty of remembering when and how something was learned).

so See Wasserman, Lempert, and Hastie, 17 Personality \& Soc Psych Bull at 34 (cited in note 24).

${ }^{\infty}$ Id. See also Brown and Solomon, 62 Acct Rev at 568-75 (cited in note 25) (finding less bias when bad outcome of a business was said to have been caused by an unexpected change in copyright law).

${ }^{61}$ See Nario and Branscombe, 21 Personality \& Soc Psych Bull at 1252 (cited in note 26); Pennington, 20 Brit J Soc Psych at 93-95 (cited in note 24); Roese and Olson, $32 \mathrm{~J}$ Exp Soc Psych at 205-18 (cited in note 26). 
duce a larger hindsight bias than materials stating that an event did not occur; ${ }^{62}$ occurrences are generally easier to explain than nonoccurrences. More so than any of the motivational theories, Fischhoff's original hypothesis seems to account for the pattern of data in the literature on the hindsight bias.

Other cognitive factors also may be at work. Some researchers have attributed at least part of the hindsight bias to selective memory for those antecedent events that would make the known outcome seem more likely. ${ }^{63}$ Although Fischhoff found no evidence to support this hypothesis, ${ }^{64}$ the results of one other study did support it. ${ }^{65}$ Selective memory and attention to various antecedent events may also be a cognitive cause of the hindsight bias, but this has yet to be sufficiently tested.

\section{Debiasing}

Fischhoff's demonstration of the hindsight bias was followed by a series of efforts to find a successful debiasing strategy-a way of evaluating the predictability of past events accurately. These efforts have been unsuccessful. Because motivational factors only partly account for the bias, attempts to increase people's incentives to make accurate judgments, such as paying subjects for correct estimates ${ }^{66}$ or urging them to "try harder, ${ }^{\$ 67}$ reduce the bias only slightly. The bias is primarily a product of cognitive processes, and only procedures that alter the mental strategies used to make judgments in hindsight have any chance of producing unbiased evaluations.

Psychologists have tried a number of different cognitive strategies to avoid the hindsight bias. Simple remedies, such as informing people about the bias ${ }^{68}$ and giving subjects repeated attempts to make judgments with feedback, ${ }^{69}$ have no effect. Several studies have reliably reduced the bias by restructuring the decisionmaking task so as to force people to "unlearn" what the outcome has taught them about the antecedent events. Slovic and

\footnotetext{
a See Christensen-Szalanski and Willham, 48 Org Beh \& Human Decision Processes at 155 (cited in note 2 ).

* See Hawkins and Hastie, 107 Psych Bull at 320-21 (cited in note 2).

${ }^{64}$ Fischhoff, $1 \mathrm{~J}$ Exp Psych at 291-92, 295-97 (cited in note 2).

is See Lynn Hasher, Mary S. Attig, and Joseph W. Alba, I Knew It All Along: Or, Did I?, $20 \mathrm{~J}$ Verbal Learning \& Verbal Beh 86, 88-94 (1981).

${ }^{66}$ See Hell, et al, 16 Memory \& Cognition at 535 (cited in note 27).

${ }^{\text {ø }}$ See Davies, 40 Org Beh \& Human Decision Processes at 51-65 (cited in note 25); Fischhoff, 3 J Exp Psych at 354-56 (cited in note 49).

${ }^{68}$ See Fischhoff, $3 \mathrm{~J}$ Exp Psych at 354-56 (cited in note 49). 27).

${ }^{\oplus}$ See Pohl and Hell, 67 Org Beh \& Human Decision Processes at 51-55 (cited in note
} 
Fischhoff asked subjects to determine whether they would be able to explain the alternative outcome if it had occurred. ${ }^{70}$ Fischhoff and his colleagues had subjects draw out a "fault tree" for all possible outcomes before assigning probabilities to these outcomes. ${ }^{71}$ Davies had subjects, in foresight, make notes on their efforts to generate the likelihood of the various outcomes and then had the subjects review these notes before trying to recall these likelihood estimates in hindsight. ${ }^{2}$ In one study, researchers had subjects generate their own descriptions of the possible outcomes. ${ }^{73}$ Finally, several researchers have tried asking subjects to provide reasons for their probability assessments. ${ }^{74}$ All of these methods forced the subjects to rethink the inferences that they made upon learning the outcome and demonstrated to them that other inferences remained plausible. Nevertheless, the subjects, judging in hindsight, still knew that there was but a single reality. Inevitably, they assigned more weight to that reality and the inferences that it inspired. As a result, these techniques reduced the size of the hindsight bias but did not produce completely unbiased judgments. ${ }^{75}$ Complete elimination of the bias has eluded psychologists.

Thus, the psychological research demonstrates that the hindsight bias is an extremely robust phenomenon. It influences judgments made in many different settings by many different types of people. The bias is also large enough to have an important impact on the legal system and has been shown to affect the two kinds of decisionmakers upon which the legal system reliesgroups (juries) ${ }^{76}$ and experienced decisionmakers (judges) ${ }^{77}$ The

${ }^{70}$ Slovic and Fischhoff, 3 J Exp Psych at 548-49 (cited in note 25).

"A "fault tree" consists of a diagram of all of the possible outcomes and the possible consequences of these outcomes and an assignment of a probability to each "branch." Baruch Fischhoff, Paul Slovic, and Sarah Lichtenstein, Fault Trees: Sensitivity of Estimated Failure Probabilities to Problem Representation, 4 J Exp Psych: Human Perception \& Performance 330, 331 (1978).

72 Davies, 40 Org Beh \& Human Decision Processes at 51-64 (cited in note 25).

${ }^{73}$ Lowe and Reckers, 25 Decision Sci at 412-15 (cited in note 36) (asking subjects to provide alternative outcomes to the outcome given them).

"See Arkes, et al, $73 \mathrm{~J}$ Applied Psych at 306-07 (cited in note 29); Davies, $27 \mathrm{~J}$ Res Personality at 229-33 (cited in note 25); Hell, et al, 16 Memory \& Cognition at 535-36 (cited in note 27 ).

${ }^{73}$ The most effective debiasing study only reduced the bias to slightly more than onehalf of the difference between the ordinary hindsight and the foresight judgments. Lowe and Reckers, 25 Decision Sci at 414 (cited in note 36).

${ }^{76}$ The results of the research on groups is particularly significant for the extension of the hindsight bias to legal judgments. It might well be the case that group decisionmaking forces individuals to discuss their reasoning in a way that facilitates debiasing. Alternatively, research shows that groups seem to polarize toward more extreme positions than individuals. See Roger Brown, Social Psychology: The Second Edition 200-48 (Free Press 
bias is a product of the normal process of integrating feedback into our understanding of the world and updating our beliefs. As such, it resists efforts to avoid it. No matter how a judgment made in hindsight is restructured, the feeling that an outcome was both inevitable and predictable is impossible to avoid. Because courts primarily judge in hindsight, the bias might exert tremendous influence on judgments in the legal system.

\section{THE HINDSIGHT BIAS IN LEGAL DECISIONS}

\section{A. Studies of the Hindsight Bias and Legal Culpability}

The research on the hindsight bias shows that people blame others for failing to have predicted adverse outcomes that could not have been predicted. ${ }^{78}$ Two studies, one by Susan and Gary $\mathrm{LaBine}^{79}$ and another by Kim Kamin and me, ${ }^{80}$ demonstrate explicitly that the bias even causes people to hold decisionmakers legally liable for outcomes that they could not have predicted. In

1986) (providing a full discussion of the phenomenon). This might exacerbate the effect of the hindsight bias. The data, however, support neither theory. Groups seem to show slightly less bias than individuals, but are still affected by the bias. Bukszar and Connolly, 31 Acad Mgmt J at 631 (cited in note 25) (groups of three to five subjects); Stahlberg, et al, 63 Org Beh \& Human Decision Processes at 51-55 (cited in note 25) (groups of three to five subjects).

"Anderson, Lowe, and Reckers, $14 \mathrm{~J}$ Econ Psych at 730 (cited in note 29) (auditors and judges); Jennings, Lowe, and Reckers (unpublished manuscript) (cited in note 30) (examining judges' dependence on outcome knowledge).

${ }^{78}$ See Carli and Leonard, $8 \mathrm{~J}$ Soc \& Clinical Psych at 338 (cited in note 26) (Rape victim blamed for failing to foresee attack.); Goggin and Range, $3 \mathrm{~J}$ Soc \& Clinical Psych at 234-35 (cited in note 26) (Family members of a suicide victim blamed for failing to have predicted the tragedy.); Lipshitz and Barak, 88 Acta Psychologica at 110-15 (cited in note 29) (Consequences of a threatened terrorist attack heavily influenced Israeli Defense Force officer's evaluations of a military commander's response to the threat.). Similarly, a series of studies have shown that people blame accountants for failing to predict adverse business outcomes even when accountants in foresight could not have predicted these outcomes. See Anderson, Lowe, and Reckers, $14 \mathrm{~J}$ Econ Psych at 725-27 (cited in note 29); Jennings, Lowe, and Reckers (unpublished manuscript) (cited in note 30); Lowe and Reckers, 25 Decision Sci at 413-14 (cited in note 36). The hindsight bias even influences evaluations of decisions made within the legal system. See Galen V. Bodenhausen, Second-Guessing the Jury: Stereotypic and Hindsight Biases in Perceptions of Court Cases, 20 $J$ Applied Soc Psych 1112, 1116 (1990) (finding that when subsequent information reveals that a verdict is inaccurate, people evaluate the quality of a jury deliberation as poor); Jonathan D. Casper, Kennette Benedict, and Jo L. Perry, Juror Decision Making, Attitudes, and the Hindsight Bias, $13 \mathrm{~L} \&$ Human Beh 291, 298-301 (1989) (Mock jurors' verdicts in a suit against police officers for an alleged Fourth Amendment violation depended upon whether the search revealed incriminating evidence or not.); Dorothy $\mathrm{K}$ Kagehiro, et al, Hindsight Bias and Third-Party Consenters to Warrantless Police Searches, 15 L \& Human Beh 305, 309-11 (1991) (Subjects' assessments of roommate's right to consent to a police search of residence is dependent on whether incriminating evidence is found.).

${ }^{79}$ Susan J. LaBine and Gary LaBine, Determinations of Negligence and the Hindsight Bias, 20 L \& Human Beh 501 (1996).

${ }^{\infty}$ Kamin and Rachlinski, 19 L \& Human Beh 89 (cited in note 4). 
their study, the LaBines presented subjects with six case histories of mentally ill patients, each of which suggested some probability of violent behavior. In each case, a psychotherapist treating the patient took a precaution against violence (for example, alerting police or warning potential victims) that had been endorsed by a majority of professional psychotherapists in a previous survey. The patient either did or did not commit violence. Subjects who read that the patient later committed a violent act were more likely to conclude that: the therapist had failed to take reasonable precautions; the therapist should have done more to prevent possible violence; they themselves would have been able to predict the violence (even though the subjects were not mental health professionals); and the violent act was foreseeable. ${ }^{81}$ Most importantly, nearly one in four of these subjects concluded that the therapist was legally negligent for failing to prevent the violence. Because of the scenario's outcome, one-quarter of the subjects judged therapists who had followed a widely approved standard of treatment as negligent. ${ }^{82}$

In the study that Kamin and I conducted, subjects were randomly assigned either to make a decision in foresight as to whether a municipality should take a precaution against flooding or to judge in hindsight whether a decision not to take the same precaution was negligent. ${ }^{83}$ In foresight, the subjects listened to an audio-taped debate of a municipal planning meeting that described the circumstances of the decision. The materials instructed subjects that they were to listen to the evidence and to decide whether the precaution should be taken based on a costbenefit analysis akin to Judge Learned Hand's formula for negligence. ${ }^{84}$ The subjects were provided with the costs of the flood and the precaution ( $\$ 1,000,000$ and $\$ 100,000$, respectively), as well as meteorological and anecdotal data. The subjects were then asked to estimate the annual probability of a flood without the precaution. ${ }^{85}$ The materials instructed the subjects that, if they found

81 LaBine and LaBine, $20 \mathrm{~L} \&$ Human Beh at 507-09 (cited in note 79).

2 Id at 510. LaBine and LaBine did not inform their subjects that the precautions taken by the therapist were approved by a consensus of mental health professionals, which might have helped the therapists in such cases defend themselves against liability. See W. Page Keeton, et al, Prosser and Keeton on the Law of Torts $\$ 32$ at 189 (West 5th ed 1984) ("Prosser on Torts").

83 Kamin and Rachlinski, $19 \mathrm{~L} \&$ Human Beh at 93-94 (cited in note 4).

st "[ $\Pi$ f the probability [of injury] be called P; the injury, L; the burden [of precautions], B; liability depends upon whether B is less than $L$ multiplied by P: i.e., whether B < PL." United States $v$ Carroll Towing Co, 159 F2d 169, 173 (2d Cir 1947) (opinion by Hand).

ss The materials stated that the precaution would completely eliminate the probability of a flood. Kamin and Rachlinski, $19 \mathrm{~L} \&$ Human Beh at 95 (cited in note 4). 
that the probability of a flood was greater than 10 percent, they should decide in favor of taking the precaution; otherwise, they should decide against taking it.

The hindsight materials provided similar information, except that they described a jury trial, rather than a planning meeting, and all of the events had already occurred. The materials stated that the defendant had decided not to take the precautions, which had then resulted in $\$ 1$ million in flood damage to the property of the plaintiff, an upstream landowner. The instructions stated that if, given the information available to the defendant before the flood, the likelihood of a flood each year was greater than 10 percent, then they should find the defendant liable; otherwise, the subjects should find the defendant not liable. The hindsight condition was identical to the foresight condition in almost all other respects. The two conditions produced markedly different results, however. In foresight only 24 percent of the subjects decided that the potential for harm merited taking the precaution; in hindsight, however, 57 percent of the subjects found a decision not to take the precaution negligent. ${ }^{86}$ Just as in the LaBines' study, in hindsight people deemed as negligent a response that they would have endorsed in foresight.

\section{B. What Types of Judgments Does the Hindsight Bias Affect?}

Courts' ex post judgments of ex ante decisions fall into three categories: (1) judgments under objective ("should have known") standards; (2) judgments under subjective ("did know") standards; and (3) judgments of what was foreseeable. The hindsight bias probably influences all three of these, albeit in slightly different ways. Courts also make many judgments in hindsight that do not require an evaluation of ex ante decisions and are therefore not subject to the influence of the hindsight bias. ${ }^{87}$

${ }^{86}$ Id at 98.

${ }^{87}$ For example, according to the Restatement (Second) of Torts, a tort defendant is the legal cause of all harm that flows from his or her negligent conduct unless "after the event and looking back from the harm to the negligent conduct, it appears to the court highly extraordinary that it should have brought about the harm." (emphasis added). Restatement (Second) of Torts $\S 435$ (2) (1965). A comment to this section makes it even more clear that the rule intentionally relies on outcome knowledge:

While the actor may be responsible for the situation, it is not necessarily a situation which he, as a reasonable man, should have expected to result from his conduct. The court, however, knows that it has resulted and in such a manner as to make the actor responsible for its creation. Knowing this, the court may well not be surprised nor regard it as highly extraordinary that the stimulus of the situation should produce the intervening act; indeed, to one knowing the situation, the intervention of the act might well appear certain or almost inevitable. 
1. Objective standards.

Of these three types of judgments, research on the hindsight bias most directly implicates objective standards. When a court must determine what someone "knew or should have known," it is especially likely to fall prey to the hindsight bias. Consider the assessment of negligence in a tort action as an example. A defendant's conduct was negligent if it created an "unreasonable risk of harm" to others, ${ }^{88}$ "which the actor should recognize at the time of his action or inaction." ${ }^{389}$ The determination of whether a defendant's conduct was unreasonable is necessarily made after the consequences of an actor's conduct are known, but this knowledge is not supposed to influence the determination of reasonableness. As Prosser and Keeton explain:

The actor's conduct must be judged in the light of the possibilities apparent to him at the time, and not by looking backward 'with wisdom born of the event.' The standard is one of conduct, rather than of consequences. It is not enough that everyone can see now that the risk [of harm] was great, if it was not apparent when the conduct occurred.90

Unfortunately, people always judge conduct on its consequences. ${ }^{91}$ The legal formulation of negligence requires a trier of fact to do something that people cannot do-see the world through the eyes of the defendant before the adverse outcome occurred. Judgments made under objective standards, such as a determination of negligence in tort, invite the hindsight bias's influence.

Restatement (Second) of Torts $\S 435(2)$ comment $d$. By affirmatively asserting that the assessment of causation should be made in light of all available information, the Restatement deliberately requests a determination that is influenced by the known outcome, even though this standard ensures that defendants will be responsible for all but the most outlandish consequences. See Keeton, et al, Prosser on Torts $\$ 43$ at 298-99 (cited in note 82) (" $[T]$ one gifted with omniscience as to all existing circumstances, no result could appear remarkable, or indeed anything but inevitable, as a matter of hindsight."). Although some have argued that rules that incorporate ex ante knowledge have adverse economic consequences, see Omri Ben-Shahar, Should Products Liability Be Based on Past or Present Scientific Knowledge? (Apr 1997) (on file with U Chi L Rev), many legal rules retain this feature.

Restatement (Second) of Torts $\$ 282$.

Id at $\$ 282$ comment g.

${ }^{\infty}$ Keeton, et al, Prosser on Torts $\S 31$ at $170 \&$ n 15 (cited in note 82), quoting Green $v$ Sibley, Lindsay \& Curr, Co, 257 NY 190, 192, 177 NE 416, 417 (1931) (opinion by Cardozo).

${ }^{91}$ See Baron and Hershey, $54 \mathrm{~J}$ Personality \& Soc Psych at 578 (cited in note 35). 


\section{Subjective standards.}

The hindsight bias also might influence subjective evaluations. Judges and juries might infer that because something was predictable, it was, in fact, actually predicted. Consider the example of liability for fraud under the federal securities laws. ${ }^{92} \mathrm{~A}$ company that fails to meet its quarterly earnings projection might find that its stock price drops when this news is announced, and the managers of such a company might be sued. ${ }^{93}$ The bias might make it easier for the plaintiff to prove that the defendants knew the earnings projection was overly optimistic. This is true even if the defendants did not, in fact, know the projection was overly optimistic.

Empirical data documenting this tendency are lacking, however. Although the hindsight bias induces people to blame others for misfortune, it is not clear whether this occurs because people assume that the victims of misfortune actually " $\mathrm{knew}$ " that they were facing potential adversity and failed to avoid it, or merely "should have known" that they were facing potential adversity. Fischhoff did demonstrate that the hindsight bias influences people's estimates of the beliefs that others hold about likely outcomes, ${ }^{94}$ but no one has empirically linked this phenomenon to mistaken attributions of intentional misconduct. Research on the hindsight bias strongly suggests that people will impute knowledge to others, but conclusive evidence is as yet unavailable. Even if subjective standards invite biased judgments, the hindsight bias probably has less influence on judgments made under subjective standards than it does on judgments made under objective standards. In a case judged under a subjective standard, evidence of a defendant's actual state of mind may be available in the form of notes or comments that the defendant made at the time the event occurred. The bias may color a factfinder's view of this evidence, but probably not as easily as it colors a judgment as to what a defendant should have known. ${ }^{95}$

${ }^{92}$ See Donald C. Langevoort, Capping Damages for Open-Market Securities Fraud, 38 Ariz L Rev 639, 644-46 (1996) (discussing the implications of the hindsight bias to the assessment of scienter in securities fraud cases).

${ }^{93}$ See Janet Cooper Alexander, Do the Merits Matter? A Study of Settlements in Securities Class Actions, 43 Stan L Rev 497, 508-09 (1991) (discussing massive derivative class action suits that follow drastic falls in a stock's price).

* Fischhoff, $1 \mathrm{~J}$ Exp Psych at 295-97 (cited in note 2).

${ }^{95}$ Although a discussion of the application of the hindsight bias to criminal law is beyond the scope of this Article, if the bias does affect subjective judgments, then it is likely to have an impact on the outcome of criminal cases. 


\section{Foreseeability.}

Finally, many areas of law require courts to determine what was "foreseeable." As distinguished from the objective standard of liability, foreseeability is qualitative. It refers to a range of possible occurrences rather than to the likelihood that any of these occurrences will come to pass. For example, in products liability, a manufacturer can be liable for injuries to a plaintiff who engaged in "foreseeable misuse" of a product. . $^{96}$

More generally in tort, a defendant is only liable for damages to foreseeable plaintiffs. ${ }^{97}$ Intuitively, it seems likely that once the outcome is known, the hindsight bias will make the outcome appear more foreseeable. Even more so than the subjective hindsight problems, however, this theory lacks data. Studies on the hindsight bias have documented its influence on probability estimates, not on what could have been envisioned. No one has conducted a careful study of exactly what makes an outcome seem "foreseeable" as opposed to "predictable."

\section{Summary.}

The remainder of this Article is devoted largely to the problem of the hindsight bias's influence on objective standards within the law. Here the analysis is reasonably clear. In the case of objective judgments, the legal system asks judges and juries to make determinations that closely resemble the questions that psychologists have used in their materials. Good faith assessments of what constitutes a reasonable course of action in foresight can easily be judged unreasonable in hindsight. Although the hindsight bias also might affect judgments of subjective knowledge or foreseeability, these theories lack empirical support. Because it seems likely that the bias does affect these two

" See Aaron D. Twerski, The Many Faces of Misuse: An Inquiry Into the Emerging Doctrine of Comparative Causation, 29 Mercer L Rev 403, 420-26 (1978). This doctrine has evolved, and the draft Restatement of Products Liability proposes that a comparative fault scheme be used to judge liability as between the manufacturer of a product and a plaintiff who misuses the product. See Restatement of the Law (Third) Torts: Products Liability $\S 11$ comment b (Tentative Draft no 3 1996).

" See Restatement (Second) of Torts $\S 281$ comment c. This assertion can be traced originally to Justice Cardozo's majority opinion in Palsgraf $v$ Long Island $R$ Co, 248 NY 339, 162 NE 99 (1928).

- LaBine and LaBine, $20 \mathrm{~L} \&$ Human Beh at 509 (cited in note 79), did report that subjects described the actual outcome of their scenarios as more foreseeable than ones that did not occur. Their data, however, does not track the legal limitation on foreseeability-that is, whether the plaintiff was a foreseeable plaintiff and the harm done was a foreseeable type of harm. See Keeton, et al, Prosser on Torts $\S 43$ at 297-300 (cited in note 82). 
types of judgments, however, this Article also includes an application of the bias to an issue judged under a subjective standard (in federal securities law) and to an issue of foreseeability (in patent law).

\section{Countervailing Influences}

In some circumstances, the hindsight bias might not have as significant an impact on the legal system as expected. The influence of the bias can be blunted by other factors or it can affect both parties to a lawsuit. For example, in tort cases, although the bias probably makes it easier for plaintiffs to prevail, tort plaintiffs generally face fairly significant hurdles to filing a lawsuit and building a case. ${ }^{99}$ In fact, few victims of negligence actually sue. ${ }^{100}$ In addition, tort plaintiffs also might face other psychological biases in the courtroom that make it difficult for them to prevail. ${ }^{101}$

Furthermore, the availability of comparative negligence as a defense might result in a process that is influenced by the bias, but that nevertheless produces unbiased judgments. If the negligence of both parties is at issue, then the defendant might benefit

${ }^{9}$ See generally Marc Galanter, Why the "Haves" Come Out Ahead: Speculations on the Limits of Legal Change, $9 \mathrm{~L} \&$ Society Rev 95 (1974).

${ }^{100}$ In medical malpractice, there are ten injuries for every plaintiff who makes a claim for compensation. See Patricia M. Danzon, Medical Malpractice: Theory, Evidence and Public Policy 22-25 (Harvard 1985). See also The Report of the Harvard Medical Practice Study, Patients, Doctors, and Lawyers: Medical Injury, Malpractice Litigation, and Patient Compensation in New York 7-1 (Harvard 1990) (analyzing trends in the use of legal recourse to recover for injuries); Troyen A. Brennan, et al, Incidence of Adverse Events and Negligence in Hospitalized Patients: Results of the Harvard Medical Practice Study I, 324 New Eng J Med 370, 371-75 (1991) (finding medical management causes substantial injuries, many of which are the result of substandard care); A. Russell Localio, et al, Relation between Malpractice Claims and Adverse Events due to Negligence: Results of the Harvard Medical Practice Study III, 325 New Eng J Med 245, 249-50 (1991) (arguing that medical malpractice litigation infrequently compensates patients). Even in automobile accidents, only about half of all injured victims of negligence pursue claims. See Alfred F. Conard, The Economic Treatment of Automobile Injuries, 63 Mich L Rev 279, 285 (1964) (Only 14 percent of persons sustaining losses due to automobile accidents hire attorneys.). See also Donald Harris, et al, Compensation and Support for Illness and Injury 46 (Clarendon 1984) ("Three-quarters of accident victims never considered the question of damages at all, and of the quarter who did, only about half actually sought legal advice about claiming."); Richard L. Abel, The Real Tort Crisis-Too Few Claims, 48 Ohio St L J 443, 448-52 (1987) (discussing the tendency of accident victims not to file claims for their injuries).

${ }^{101}$ See Neal Feigenson, Jaihyun Park, and Peter Salovey, Effect of Blameworthiness and Outcome Severity on Attributions of Responsibility and Damage Awards in Comparative Negligence Cases (forthcoming I \& Human Beh) (describing an antiplaintiff bias among jurors); Valerie P. Hans and William S. Lofquist, Jurors' Judgments of Business Liability in Tort Cases: Implications for the Litigation Explosion Debate, 26 I \& Society Rev 85, 108 (1992) (presenting evidence that jurors are skeptical of plaintiffs' motives, not defendants' motives in mounting a defense). 
from the bias in roughly the same proportion as the plaintiff. A judge or jury might condemn both litigants in a tort suit for failing to apprehend the true probability of potential injury-thereby leading, on balance, to an unbiased assignment of fault. Thus, in cases judged under a comparative fault rule, the hindsight bias might not have much impact on judgment or might even favor defendants. In these cases, the judgment might be doubly biased, resulting in a final determination approximating an accurate apportionment of fault. In a system in which the plaintiffs who are found negligent may not recover (contributory negligence), ${ }^{102}$ the bias may put the plaintiff at a comparative disadvantage to the defendant. ${ }^{103}$ These effects are speculative, because no research is available on whether the hindsight bias has more effect in judgments of the plaintiff's' or defendants' actions. ${ }^{104}$

\section{THE CONSEQUENCES OF BIASED JUDGMENTS IN HINDSIGHT}

Although direct evidence of the hindsight bias in actual cases is unavailable, nothing about the transition from the laboratory to the courtroom suggests that judgments in actual cases are free from the influence of the hindsight bias. ${ }^{105}$ The bias is large enough to be of concern to the legal system. Furthermore, there is no evidence that the use of groups (juries) or experienced decisionmakers (judges) helps avert the bias. Even in circumstances in which the bias affects both sides of a lawsuit, it is still a powerful force in litigation. Legal judgments made under objective standards are, therefore, probably tainted by the hindsight bias, thereby resulting in incorrect judgments of liability.

${ }^{102}$ See Keeton, et al, Prosser on Torts $\$ 65$ at 461 (cited in note 82).

${ }^{100}$ The hindsight bias probably affects modified comparative systems, in which a plaintiff who is at least as responsible for his or her injury as the defendant cannot recover, see Keeton, et al, Prosser on Torts $\$ 76$ at 473 (cited in note 82), the same way that it affects comparative systems-making both parties look more culpable.

${ }^{10}$ One study found that increasing the severity of the outcome caused mock jurors to increase the blame they assigned to victims of accidents (plaintiffs) rather than to injurers (defendants). Feigenson, Park, and Salovey (forthcoming L \& Human Beh) (cited in note 101). This suggests that the hindsight bias influences judgments of plaintiffs more so than defendants.

${ }^{105}$ Simulation studies of jury decisionmaking like those by the LaBines and Kamin and me have been criticized for failing to replicate the detail and gravity of judgments made in actual cases. See Robert M. Bray and Norbert L. Kerr, Methodological Considerations in the Study of the Psychology of the Courtroom, in Norbert L. Kerr and Robert M. Bray, eds, The Psychology of the Courtroom 287, 305-08 (Academic 1982). But see Robert J. MacCoun, Experimental Research on Jury Decision-Making, 244 Sci 1046, 1046 (1989) (concluding that "mock jurors do not appear to reach decisions by a fundamentally different process than actual jurors"). 
Mistakes are doubtlessly common in the legal system and probably do not have significant adverse consequences on the system as a whole. ${ }^{106}$ Systematic errors, however, are more worrisome. They can prejudice a particular group or class and can undermine the law's ability to induce potential defendants to take reasonable precautions against injuring others. ${ }^{107}$ The hindsight bias is a systematic error with the capacity to distort the legal system in undesirable ways.

\section{A. The Economic Consequences of the Hindsight Bias}

Intuitively, treating parties as if they were negligent even though they took reasonable precautions seems likely to have adverse economic consequences. Holding defendants who were not negligent liable, however, is nothing more pernicious than a system of strict liability. In effect, the hindsight bias converts the negligence standard into a de facto system of strict liability. Negligence judgments influenced by the hindsight bias should therefore have economic consequences similar to those of a system of strict liability.

Strict liability does not create incentives for potential defendants to take an excess of precautions. ${ }^{108}$ Under both negligence and strict liability, potential defendants minimize their costs by taking all socially efficient precautions. Both systems would appear to create adequate incentives to take efficient precautions. There are, however, two caveats. First, the possibility that the defendant or the ultimate trier of fact will make errors in determining due care might, in a negligence system, cause potential defendants to undertake an inefficient excess of precautions. Defendants experience a sharp benefit from increasing their precautions from just below reasonable care to just above it. Therefore, if there is any uncertainty about what constitutes reasonable care, defendants should err in favor of an excess of precautions. ${ }^{109}$ Second, because strict liability forces potential defendants to pay

\footnotetext{
${ }^{106}$ See Mark F. Grady, A New Positive Economic Theory of Negligence, 92 Yale L J 799, 814-21 (1983); R. Posner, Economic Analysis of Law at 549-52 (cited in note 6). But see John E. Calfee and Richard Craswell, Some Effect of Uncertainty on Compliance with Legal Standards, $70 \mathrm{Va} L \mathrm{Rev} 965,974-89$ (1984) (arguing that errors can create adverse consequences).

${ }^{107}$ See Calfee and Craswell, 70 Va L Rev at 971-74.

${ }^{100}$ See William M. Landes and Richard A. Posner, The Economic Structure of Tort Law 64 (Harvard 1987); A. Mitchell Polinsky, An Introduction to Law and Economics 40-42 (Little, Brown 2d ed 1989); R. Posner, Economic Analysis of Law at 175 (cited in note 6); Steven Shavell, Strict Liability Versus Negligence, 9 J Legal Stud 1, 2-9 (1980).

${ }^{109}$ See Calfee and Craswell, 70 Va L Rev at 971-74. But see Grady, 92 Yale L J at 81921 (arguing that the negligence system accommodates this uncertainty efficiently).
} 
for all of the injuries that result from an activity, as opposed to only those that result from negligence, an activity is more expensive under strict liability than under negligence. ${ }^{110}$ With the exception of these two issues, however, classic law and economics models of liability suggest that a system of strict liability would closely resemble a system of negligence.

The hindsight bias changes the economic comparison between negligence and strict liability. A system of negligence judged with the hindsight bias is similar to, but not the same as, a system of strict liability; it is essentially a "quasi-strict" liability rule. The bias causes courts to hold defendants who took reasonable care liable, much as they would under a strict liability rule. But, because even a biased assessment of reasonable care can result in a finding that the defendant was not negligent, the two systems differ somewhat. Defendants who have taken precautions that are far greater than reasonableness requires (as determined in foresight) probably still will be free from liability, in spite of the bias. Defendants who have taken precautions that are barely adequate probably will be found negligent because of the hindsight bias. The amount that potential defendants will have to spend beyond the socially efficient level of care to be free from liability depends upon the size of the bias, the costs of the excess precautions, and the impact of these precautions on the probability of an adverse outcome. If the savings that potential defendants realize from taking enough precautions to be immune from "quasi-strict" liability exceed the costs of these precautions, then defendants will take this socially excessive level of precautions.

A negligence rule judged in hindsight will not necessarily produce a socially inefficient result, however. When the costs of the excess precautions are greater than the savings from being found not liable, potential defendants will minimize their costs at the socially efficient level of precautions, even though they will have to pay for the damages that the plaintiffs suffer. ${ }^{111}$

${ }^{110}$ See Landes and R. Posner, The Economic Structure of Tort Law at 64-73 (cited in note 108); R. Posner, Economic Analysis of Law at 175-80 (cited in note 6); Shavell, $9 \mathrm{~J}$ Legal Stud at 23 (cited in note 108).

"If If potential defendants systematically underestimate the likelihood of an accident in foresight, then they would be taking inefficient levels of precautions, absent the hindsight bias. In such a scenario, the hindsight bias might undo some of the adverse effects of such underestimates. The size of the effect of the hindsight bias, however, would not necessarily match the degree to which potential defendants are underestimating the probability of an accident. The combined effect might result in overdeterrence, as described in the text, or in underdeterrence. This Article does not address the possibilities of ex ante underestimation, although such an effect is a possibility. 
Figure 1 depicts this by graphing the costs that the liability system, judged in hindsight, will likely impose on potential defendants. The $X$ axis represents the level of precautions the defendant may take and the $Y$ axis indicates the cost of accidents and precautions. Defendants who are judged non-negligent pay only for the cost of the precautions, while defendants who are judged negligent pay for the cost of the precautions plus the damages caused to the plaintiffs. Total social costs (the cost of the accident plus the cost of the precautions) are at their lowest at point $P$ on the graph. Under the conventional economic analysis, defendants are not negligent if they take a level of care of at least that marked by point $P$. They minimize their costs at point $P$ under either a negligence or strict liability rule-the only difference being that under a negligence rule, their costs are $Q_{1}$ while under a strict liability regime their costs are Q3.

\section{Figure 1: Cost of Accidents and Precautions}

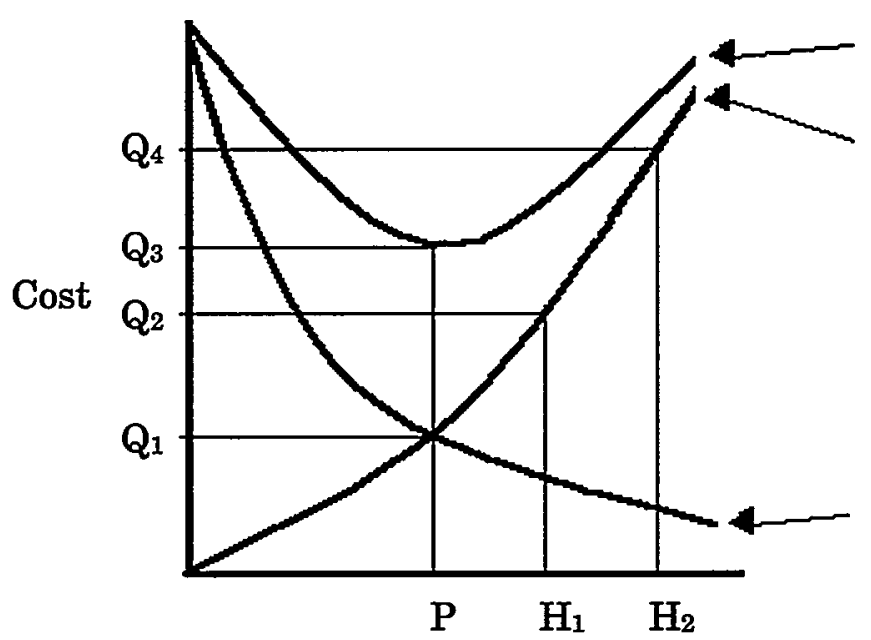

Cost of accidents plus precautions

Cost of precautions

Cost of accidents

Level of Precautions

The hindsight bias increases the level of care at which courts judge defendants not negligent. Therefore, if the bias moves this point to $\mathrm{H}_{1}$, defendants who only take the socially efficient level of care $(\mathrm{P})$ will have to pay for both the cost of the precautions and the cost of the accident $\left(Q_{3}\right)$ just as defendants do in strict liability. However, if the defendants take the higher level of care $\left(\mathrm{H}_{1}\right)$, they will be required to pay only for the cost of the precautions $\left(Q_{2}\right)$. Thus, because their overall costs will be less, the defendants will take the higher level of care $\left(\mathrm{H}_{1}\right)$. The private savings that these defendants realize from taking an excess of precautions 
outweigh the private costs of these precautions, leading to incentives for defendants to be inefficient. If the effect of the hindsight bias is larger than this, however, and courts exonerate only defendants who take a level of care of at least that marked by point $\mathrm{H}_{2}$, defendants will now minimize their costs at the efficient level of $P$. This is because, at $\mathrm{H}_{2}$, defendants pay $\mathrm{Q}_{4}$ in costs for precautions, which exceeds Q3.

Thus, the presence of the hindsight bias in the negligence system has an indeterminate effect on incentives to take adequate precautions. If the consequences of the bias are so severe as to make negligence resemble strict liability, it might produce incentives to be efficient. Under different conditions, however, it also might create incentives to take an excess of care. Neither common law judges nor legislators are likely to have the capacity to distinguish which of these two situations any class of cases follows. It would take a wealth of econometric data on the cost of accidents and precautions, along with a precise quantification of the hindsight bias and its relationship to these precautions, in order to determine whether judging negligence in hindsight creates incentives to take an excess of precautions in any given context. It would be difficult, if not impossible, for a court to determine whether negligence judged in hindsight creates inefficient incentives. ${ }^{112}$ Therefore, retaining a negligence system, despite its biases in judgment, might be the optimum, albeit imperfect, alternative for courts to pursue.

The hindsight bias might have another unintended economic effect. As noted above, conventional economic analysis concludes that strict liability imposes higher costs on potential defendants than negligence does. ${ }^{113}$ Incorporating the hindsight bias into the analysis, however, either reduces or eliminates this difference. If the relationship between accidents, precautions, and the hindsight bias induces defendants to take an excess of precautions, potential defendants will face somewhat higher costs than an analysis without the hindsight bias predicts. Specifically, they will have to pay for the excess of precautions needed in order to avoid liability.

${ }^{112}$ Even defendants might have difficulty determining whether they should take an excess of precautions or not under the circumstances that they face. Repeat defendants, such as insurance companies and manufacturers, probably have adequate data to make this determination, because they will know the relationship between their expenditures on precautions and the expected costs of liability.

"'see Landes and R. Posner, The Economic Structure of Tort Law at 64-73 (cited in note 108); R. Posner, Economic Analysis of Law at 175-80 (cited in note 6); Shavell, $9 \mathrm{~J}$ Legal Stud at 4-5 (cited in note 108). 
If the relationship between accidents, precautions, and the hindsight bias induces defendants to take the efficient level of precautions, however, then both negligence and strict liability impose the same costs on defendants. Under these circumstances, regardless of the rule, defendants will take only reasonable care and incur liability for the costs of the accidents that their activity causes. If the cost of the excess precautions exceeds the savings in liability that defendants realize, then the choice between negligence and strict liability has no effect on the social cost of the underlying activity. ${ }^{114}$

A system that produced unbiased judgments would, therefore, avoid one of two adverse economic consequences of the hindsight bias. ${ }^{115}$ First, unbiased judgments would avoid the possibility that the hindsight bias would create incentives to undertake an excess of precautions. Second, in those circumstances in which judging negligence in hindsight produces the same incentives as strict liability, the costs of de facto strict liability might make the underlying activity undesirably expensive. Regardless of whether the cost of excess precautions exceeds the savings in liability to the defendant, judging negligence in hindsight is second best to an unbiased system.

\section{B. Fairness and the Hindsight Bias}

Economics aside, the hindsight bias might simply make judging liability in hindsight unfair. The bias seems to produce unjust results; it ensures that potential defendants cannot rely on the legal standard to avoid liability. Hindsight, in effect, raises the bar after an accident. Shifting legal standards have long been identified as inequitable. As a seventeenth century court put it: "a law which a man cannot obey, nor act according to it, is void and no law. ${ }^{1116}$ Subjecting parties to standards that increase after the fact resembles ex post facto laws. In the criminal context, the United States Constitution expressly forbids ex post facto laws ${ }^{117}$

${ }^{11}$ Defendants who, for whatever reason, take an excess of precautions will pay less under a negligence system than a strict liability system. Such defendants will be spending much more than they need to, however.

${ }^{115}$ Simply adopting a system of strict liability instead of negligence would also avoid the possibility that negligence judged in hindsight would create incentives to take socially excessive precautions. This solution might have other adverse consequences, however. See text accompanying notes 108-10.

${ }^{116}$ Thomas v Sorrell, Vaughan 330, 124 Eng Rep 1098, 1102 (KB 1677).

${ }^{117}$ US Const Art I, \& 9, cl 3. The Constitution does not prohibit ex post facto civil liability unless such liability is punitive in nature. United States Trust Co v New Jersey, 431 US 1, 17 n 13 (1977). Retroactive civil liability violates the Due Process Clause of either the Fifth or Fourteenth Amendments if its consequences are "harsh and oppressive." Welch $v$ 
because the "[f]ramers sought to assure that legislative acts give fair warning of their effect and permit individuals to rely on their meaning until explicitly changed."118 The bias converts an announced negligence rule into a strict liability rule in application. An incongruence "between the rules as announced and their actual administration" such as this smacks of injustice. ${ }^{119}$

Liability judged in hindsight, however, is less unjust in practice than this analysis suggests. No court has access to the kind of information that would indicate that its judgment is biased by hindsight. A demonstration of the hindsight bias requires comparing the probability estimates of people who learn that a decision turned out badly with the estimates of those who do not know the consequences of that decision. In contrast, judges and juries know only their own probability estimates, made in hindsight. With only half of the picture, a court might be unaware of the influence that the hindsight bias has on its assessment of a party's ex ante actions. Although people generally are aware of the bias, at the same time they believe that they have assessed the predictability of the events correctly. ${ }^{120}$ Any single case will appear to have been correctly and fairly adjudicated. In fact, a correction might seem less fair than an uncorrected, biased judgment.

Imagine a case in which a defendant has taken slightly more precautions than reasonable care, as judged in foresight, requires. Suppose that the hindsight bias causes people judging in hindsight to exaggerate the ex ante probability of the adverse outcome, and as a result, the jury finds the defendant negligent. A correction for the hindsight bias would require that this defendant be exonerated, despite the fact that the judge, jury, plaintiff, and maybe the defendant now believe that the defendant was negligent. Rather than the biased hindsight judgment seeming unfair, a judgment corrected for the hindsight bias would seem unfair, especially if the case involves a severely injured tort plaintiff.

Furthermore, potential defendants should understand that, if their actions injure another, a court necessarily will judge them in hindsight. Potential defendants can either adjust their level of care to avoid liability by taking a slight excess of precautions, or they can act as if they will be judged under a standard of strict li-

Henry, 305 US 134, 146-47 (1938).

${ }^{113}$ Weaver $v$ Graham, 450 US 24, $28-29$ (1981).

${ }^{11}$ Lon L. Fuller, The Morality of Law 39 (Yale rev ed 1969) (identifying this problem as one of the ways in which the Rule of Law can miscarry).

${ }^{200}$ See Fischhoff, $1 \mathrm{~J}$ Exp Psych at 298 (cited in note 2). 
ability. Although the hindsight bias creates an incongruence between the law as announced and the law as applied, it is neither an unpredictable nor an unexpected incongruence. Biased assessments in hindsight are well-understood, and it is therefore not necessarily unfair to subject potential defendants to them.

Nevertheless, an unbiased judgment clearly would be superior to a biased one. Over time, repeat players might notice the tendency of biased judgments to raise standards after the fact, as might judges. This could undermine the perceived fairness of the system of civil liability. Furthermore, the choice of a negligence system rather than a strict liability system might reflect a careful balancing of the liberty interests of the injurers against the security interests of the victims ${ }^{121}$ - a balance that the hindsight bias disrupts. In addition to economic superiority, a stable standard probably would be more fair, even if correcting for the hindsight bias would make individual applications seem unfair.

\section{ADAPTATIONS IN THE LEGAL SYSTEM}

Long before empirical studies proved its existence, the hindsight bias has been part of folk wisdom. Therefore, it seems likely that the legal system has developed adaptations to the bias's influence. Avoiding the influence of the hindsight bias altogether, however, is probably impossible. Because the bias is so deeply ingrained into the human judgment process, psychologists have been unable to develop a way to induce people to make unbiased ex post judgments of ex ante probabilities. Even if courts understand that judging liability in hindsight generates biased results, they might be powerless to do anything about it. Although general procedures that avoid the bias in all cases are unlikely to be available, in some specific circumstances, the courts have opportunities to reduce the bias's influence. In most cases, however, because the bias makes accurate judgments unavailable, the courts must struggle to develop a second-best method of assigning liability.

\section{A. General Procedures to Avoid Biased Judgments}

Judicial instructions, suppression of evidence, and the standard of persuasion are the usual "quality control" mechanisms for judgment in the courtroom. To aid a jury in reaching a rational decision, the judge structures the trial and provides instructions

${ }^{22}$ See Jules Coleman and Arthur Ripstein, Mischief and Misfortune, 41 McGill L J 91, 110-12 (1995) (analyzing the interplay between liberty and security in the debate over negligence and strict liability). 
on how to decide the case. Judges also suppress misleading evidence. ${ }^{122}$ The standard of persuasion also is set so as to advance rational functioning of the legal system. None of these methods, however, can be used to ameliorate the hindsight bias satisfactorily.

Psychologists have uncovered no way to instruct people on how to evaluate decisions in hindsight in a way that completely avoids the hindsight bias. Judicial instructions are unlikely to include a mechanism that would fare any better. The study that Kamin and I conducted shows how difficult it would be to use judicial instructions that even partially debias judgments made in hindsight. ${ }^{123}$ In addition to measuring the influence of hindsight on judgments of negligence, this study tested a debiasing strategy using judicial instructions. The materials in this study warned half of the subjects in the trial that "a fair determination of probability may be difficult" because "hindsight vision is always 20/20." ${ }^{\text {"124 }}$ The materials instructed the subjects to "take a moment to think of all the ways in which the event in question may have happened differently or not at all." ${ }^{2125}$ This debiasing procedure had no effect. ${ }^{126}$

Passive debiasing instructions, such as those used by Kamin and me, are insufficiently intrusive to counteract the hindsight bias. The effective strategies that psychologists have used to reduce the bias all require much more invasive procedures, such as drafting a fault tree ${ }^{127}$ or considering and explaining alternative outcomes. Because they are so intrusive, these procedures may not be suitable for the courtroom. The debiasing procedures that psychologists have found to be partly successful surpass the traditional techniques that courts use to control jury decisionmaking. Furthermore, even if a debiasing technique could be successfully shoe-horned into the trial context, it would still only partly reduce the effect. No strategy has been found for completely avoiding the bias.

In fact, courts do not attempt to use judicial instructions as a means of debiasing jurors. Instructions typically ask for unbiased ex post judgments of ex ante probabilities without suggesting how to accomplish this complex cognitive task. For example, the California Bar Association Jury Instructions ("BAJI") simply re-

\footnotetext{
${ }^{12}$ See, for example, FRE 403.

${ }^{123}$ Kamin and Rachlinski, $19 \mathrm{~L} \&$ Human Beh at 97-98 (cited in note 4).

${ }^{224}$ Id at 97.

${ }^{225} \mathrm{Id}$.

${ }^{120}$ Id at 98.

${ }^{12}$ See note 71.
} 
quire juries in negligence cases to evaluate whether "a person of ordinary prudence ... in the same situation and possessed of the same knowledge . . . would have foreseen or anticipated that someone might have been injured by . . . his action or inaction."128 The BAJI do not even recommend that a court give so much as a warning to the jury as to the difficulty of making this assessment, much less include a debiasing instruction. Other jurisdictions follow similar patterns. ${ }^{129}$ Jury instruction manuals lack general instructions on how to avoid the hindsight bias, even though they include instructions that require juries to make judgments that will almost certainly be biased. ${ }^{130}$

Another procedure, which is somewhat more invasive than judicial instructions, is also available to the courts-special verdict forms. ${ }^{131}$ Special verdict forms break down the facts needed to support a cause of action or a defense into separate findings for a jury. ${ }^{132}$ Even this procedure is far less invasive than the psychologists' debiasing strategies, however. Special verdict forms merely require yes or no responses; they do not demand detailed explanations and do not ask juries explicitly to consider alternative accounts or "fault trees." In fact, courts do not use special verdict forms as a debiasing technique. Instead, they use them to ensure that the jury understands the separate elements of the cause of action and to narrow the issues for a retrial in the event of a successful appeal. ${ }^{133}$ Modifying special verdict forms to incorporate debiasing would be a significant departure from past practices. Such modifications would unduly intrude on the deliberative process of the jury and possibly run afoul of the Seventh Amendment guarantee of the right to a civil jury. ${ }^{134}$ Furthermore, the empiri-

${ }^{128}$ BA.JI $\S 3.11$ (West 7th ed 1986).

${ }^{12}$ See, for example, 1A New York Pattern Jury Instructions-Civil § 2:10 (Law Co-op 3d ed 1997). But see Edward J. Devitt, Charles B. Blackmar, and Michael A. Wolff, 3 Federal Jury Practice and Instructions-Civil § 80.07 (West 4th ed 1987) (exhibiting a light attempt to debias by instructing the jury that "the mere fact that an accident happened ... does not permit the jury to draw the inference that the accident was caused by anyone's negligence").

${ }^{130}$ Instructions are available that implement a substantive restriction that juries refrain from inferring negligence based only on the occurrence of an adverse outcome. See note 129. This issue is discussed in Part IV.B.3.

${ }^{131}$ FRCP 49 (a) authorizes the use of special verdict forms in the federal courts.

${ }^{132}$ See FRCP 49 (a) (" $[T]$ he court may require a jury to return only a special verdict in the form of a special written finding upon each issue of fact.").

${ }^{133}$ See Charles A. Wright, The Law of Federal Courts $\$ 94$ at 674-76 (West 5th ed 1994); Charles A. Wright, The Use of Special Verdicts in Federal Court, 38 FRD 199, 20106 (1966).

${ }^{134}$ See Jorgenson v York Ice Machinery Corp, 160 F2d 432, 435 (2d Cir 1947) (expressing reluctance to constrain deliberative process of the jury). 
cal evidence on special verdict forms suggests that they have little effect on jury decisionmaking. ${ }^{135}$

Another common legal mechanism for avoiding bias and prejudice-suppressing evidence-probably cannot cure the hindsight bias. To avoid the influence of the bias, the evidence that needs to be suppressed is the very fact that some adverse event led to a lawsuit. Courts have used juries to make findings of fact in the absence of both the injured parties and descriptions of their injuries. ${ }^{136}$ This kind of bifurcation of a trial does seem to affect jury decisionmaking, ${ }^{137}$ thus, some have advocated using bifurcation procedures to eliminate the influence of the hindsight bias. ${ }^{138}$ Even in these bifurcated trials, however, juries cannot remain completely unaware of the existence of injured plaintiffs. ${ }^{139}$ In some circumstances, courts do suppress evidence that would exacerbate the impact of the hindsight bias on judgment; ${ }^{140}$ evidence that would create the conditions for biased judgment, however, cannot be eliminated from the trial process. Hiding the extent of injuries will not eliminate the hindsight bias, because the severity of the outcome does not alter the bias's influence on assessments of responsibility. ${ }^{141}$ The mere fact of an adverse outcome creates a biased judgment, and this fact cannot be suppressed from evidence or eliminated from the jury's knowledge by a special procedure.

Allocating the burden of persuasion against the party likely to benefit from the hindsight bias could compensate for its influ-

${ }^{135}$ See Elizabeth C. Wiggins and Steven J. Breckler, Special Verdicts as Guides to Jury Decision Making, 14 L \& Psych Rev 1, 1-2 (1990) (Jurors render their verdicts "on the basis of overall impressions, rather than on an orderly consideration of the relevant issues.").

${ }^{136}$ See In re Richardson-Merrell, Inc "Benedectin" Products Liability Litigation, 624 F Supp 1212, 1222-23 (S D Ohio 1985), affd as Hoffman v Merrell Dow Pharmaceuticals, Inc (In re Benedectin Litigation), 857 F2d 290 (6th Cir 1988). See also FRCP 42(b) (allowing bifurcation of issues). For a full discussion of issue separation, see James A. Henderson, Jr., Fred Bertram, and Michael J. Toke, Optimal Issue Separation in Modern Products Liability Litigation, 73 Tex L Rev 1653, 1675-96 (1995) (outlining which types of issues are best adjudicated in a bifurcated trial scenario).

${ }^{137}$ See Irwin A. Horowitz and Kenneth S. Bordens, An Experimental Investigation of Procedural Issues in Complex Tort Trials, 14 L \& Human Beh 269, 281-85 (1990) (finding bifurcation of issues resulted in more verdicts for defendant but higher average damage awards).

${ }^{138}$ See Arkes and Schipani, 73 Or L Rev at 633-36 (cited in note 8) (advocating this procedure as a means of reducing the impact of the hindsight bias).

${ }^{139}$ See David B. Wexler and Robert F. Schopp, How and When to Correct for Juror Hindsight Bias in Mental Health Malpractice Litigation: Some Preliminary Observations, 7 Beh Sci \& L 485, 494 (1989) ("The jury will undoubtedly know that they are not being asked simply to engage in academic exercise.").

${ }^{140}$ See Part IV.B.4.

${ }^{141}$ See Walster, 20 Human Rel at 247-48 (cited in note 14). This study did show, however, that the magnitude of the outcome can influence the size of the bias. Id at 244-47. 
ence. In most civil cases, the plaintiff is, in fact, both the primary beneficiary of the influence of the hindsight bias and the party that must carry the burden of persuasion. The most common standard of persuasion, however, "preponderance of the evidence," is probably too low to compensate for the bias. As applied to a determination of negligence, for example, the plaintiff must show that it is more likely than not that the defendant failed to exercise reasonable care. This requirement makes it slightly more difficult for the plaintiff to win the case, but the hindsight bias easily dwarfs the effect that this standard has on the judgment. The bias gives an average of a 15 percent "boost" to the assessed probability in foresight ${ }^{142}$-easily enough to enable the plaintiff to surmount the 50 percent threshold needed to establish liability in a close case. ${ }^{143}$

Raising the standard of persuasion, by requiring "clear and convincing evidence" for findings that the bias is likely to affect, might undo its impact on the judgment. Increasing the standard of persuasion is rare in civil cases, but courts allow it in instances where "there is thought to be special danger of deception, or where the court considers that the particular type of claim should be disfavored on public policy grounds. ${ }^{\text {"144 }}$ This description implies that the standard should be used to eliminate bias, but increasing the standard of persuasion would be an inappropriate response to the hindsight bias. As a preliminary matter, it is not entirely clear that the standard of persuasion actually influences the outcome of cases. ${ }^{145}$ Even if raising the standard would make it more difficult for a party relying on the hindsight bias to win a case, this reform would treat the symptom and not the disease. The effect of increasing the standard would be unlikely to match the effect of the hindsight bias perfectly. It might overcompensate

${ }^{142}$ See Part I.A.

${ }^{14}$ See David Kaye, The Laws of Probability and the Law of the Land, $47 \mathrm{U}$ Chi L Rev 34, 47-56 (1979) (defending the proposition that the preponderance of the evidence standard is properly defined as requiring that there be at least a 50 percent chance that the defendant is liable); David Kaye, The Limits of the Preponderance of the Evidence Standard: Justifiably Naked Statistical Evidence and Multiple Causation, 1982 Am Bar Found Res $J$ 487, 492-503 (considering the application of probability ratios in joint tortfeasor/multiple defendant situations). See also Neil Orloff and Jery Stedinger, A Framework for Evaluating the Preponderance-of-the-Evidence Standard, $131 \mathrm{U}$ Pa L Rev 1159 (1983) (providing a thorough discussion of the preponderance of the evidence standard).

1" Edward W. Cleary, ed, McCormick on Evidence $\$ 340$ at 961 (West 3d ed 1984).

${ }^{\text {us }}$ See Dorothy K. Kagehiro and W. Clark Stanton, Legal vs. Quantified Definitions of Standards of Proof, 9 L \& Human Beh 159, 163-73 (1985) (Empirical study showing that the different standards of persuasion produced similar jury verdicts.). But see Kevin $M$. Clermont, Procedure's Magical Number Three: Psychological Bases for Standards of Decision, 72 Cornell L Rev 1115, 1148 (1987) (arguing that each commonly used standard of persuasion has a distinct psychological meaning). 
for the bias. Raising the standard of persuasion to "clear and convincing evidence" might make it too difficult for plaintiffs to win against defendants who were in fact negligent. ${ }^{146}$

For example, imagine a negligence case in which the costs and benefits of precautions and accidents are such that a defendant should be found liable if the probability of an accident is 20 percent or greater. Suppose that the defendant determines in foresight (in good faith) that the probability of an accident is only 10 percent. If the hindsight bias makes an ex ante probability estimate of 10 percent look like it should have been 25 percent, in the event of an accident this defendant is likely to be improperly judged negligent under the preponderance of the evidence standard. Suppose further that raising the standard of liability to "clear and convincing evidence" makes the jury more skeptical; so much so that they now demand a showing that the actual probability of an accident was 50 percent in order to find the defendant negligent. The defendant in this example will now properly be exonerated, but the standard is so high that any defendant who faced potential accidents with ex ante likelihoods of between 20 percent and 35 percent would be incorrectly found not liable. If many more potential defendants in similar circumstances face accidents with likelihoods of between 20 percent and 35 percent than face accidents with likelihoods of between 5 percent and 20 percent, then elevating the standard of proof to require "clear and convincing evidence" will increase the number of incorrect results. Raising the standard creates the potential for more errors in judgment than the hindsight bias caused. It is perhaps not surprising then that courts do not manipulate the standard of persuasion as a means of avoiding the hindsight bias.

\section{B. Remedies for the Hindsight Bias in Specific Circumstances}

The usual methods for promoting rational decisionmaking in the courtroom are unlikely to eliminate the influence of the hindsight bias on judgments. Courts do not even attempt to issue instructions that might reduce the bias; they could not suppress enough evidence to avoid the bias; and increasing the burden of proof risks increasing the likelihood of error. This is not to say that the courts are ignorant of the hindsight bias or completely impotent to respond to it. In certain circumstances the courts can, and do, use techniques to avoid rendering biased judgments or to reduce the effect of the hindsight bias. Several examples support

${ }^{146}$ Raising the standard to the criminal standard, "beyond a reasonable doubt," would probably have a similar, albeit greater, effect. 
the theory that courts do understand the hindsight bias and correct for it when it is possible to do so.

\section{Compliance with ex ante norms.}

A reliable judgment of reasonable care that was made before an accident has occurred is sometimes available. Many customary practices within an industry or a profession are attempts to identify precautions that constitute a reasonable level of care. So are many government safety regulations. In such cases, rather than conducting an open-ended inquiry into whether a defendant took reasonable precautions, a court could assess whether the defendant complied with the relevant custom or regulation. Under this rule, only a determination that the defendant had not complied with the ex ante norm could support a conclusion that the defendant was negligent. ${ }^{147}$ This decision rule would avoid the need to determine ex post an ex ante probability, which an assessment of reasonableness otherwise demands, thereby eliminating much of the hindsight bias's influence on the judgment. ${ }^{148}$

Despite this advantage, the law does not recognize compliance with either custom or regulation as a complete defense to liability. ${ }^{49}$ Courts treat compliance with a custom or regulation as evidence that a tort defendant's actions were not negligent, but

${ }^{317}$ The regulatory compliance defense has several supporters. See Richard C. Ausness, The Case for a "Strong" Regulatory Compliance Defense, 55 Md L Rev 1210, 1221-23, 126567 (1996) (Administrative cost savings offset any negative effects in product safety or victim compensation.); James A. Henderson, Jr., Manufacturers' Liability for Defective Product Design: A Proposed Statutory Reform, 56 NC L Rev 625, 625-26 (1978) (Integrity of the judicial process depends on limiting products liability recovery.); Peter Huber, Safety and the Second Best: The Hazards of Public Risk Management in the Courts, 85 Colum L Rev 277, 329-35 (1985) (Regulatory agencies are best equipped for making ex ante reasonableness determinations.). Professor Richard Epstein has provided the most vigorous argument for custom as a complete defense to liability. Richard A. Epstein, The Path to The T.J. Hooper: The Theory and History of Custom in the Law of Tort, $21 \mathrm{~J}$ Legal Stud 1, 6-11 (1992).

${ }^{16}$ The hindsight bias also might make it difficult for a defendant to establish that his or her actions actually complied with the custom or regulation. See Arkes and Schipani, 73 Or L Rev at 597-601 (cited in note 8). A judge or jury, faced with an adverse outcome that, psychologically, needs to be explained, might disregard the decision rule and simply find the defendant negligent. If the hindsight bias operates this way, it would be hard or even impossible to avoid its effects. There is no evidence, however, that the bias induces judges or juries to disregard the decision rule.

${ }^{149}$ See Restatement (Second) of Torts $\$ 288 \mathrm{C}$ ("Compliance with a legislative enactment or an administrative regulation does not prevent a finding of negligence where a reasonable man would take additional precautions."); id at \$ 295A ("In determining whether conduct is negligent, the customs of the community, or of others under like circumstances, are factors to be taken into account but are not controlling where a reasonable man would not follow them."). In contrast, the failure to comply with a regulation can constitute negligence per se. See id at § 288B. 
courts independently assess the reasonableness of the defendant's actions. ${ }^{150}$ Merely introducing evidence that conduct complied with custom or regulation might reduce the impact of the hindsight bias, but, because the judge or jury still assesses the ex ante probability of the adverse event, the bias will still influence the judgment. But if the courts are aware of the influence of the hindsight bias, why is compliance with custom or regulation not a complete defense to liability? The reasons differ for custom and regulatory compliance, but both have features that have led the courts to reject them as substitutes for case-by-case determinations of reasonableness.

Problems with the regulatory compliance defense arise principally from the fact that federal agencies are the usual sources of safety regulations. Although many federal statutes require an ex ante judgment of what constitutes a reasonable level of safety, ${ }^{151}$ they might promote practices that do not constitute reasonable care. An agency might be "captured" by an industry and produce regulations that are overly sympathetic to the industry. ${ }^{152}$ Even if they are not captured, agencies are subject to intense political pressures that often lead them to develop safety standards that reflect political compromise, rather than a careful assessment of safety. ${ }^{153}$ Agencies also frequently lack the resources necessary to set safety standards properly. ${ }^{154}$ Even if they can set appropriate standards initially, regulatory agencies, subject to political pressures and tight budgets, may be unable or unwilling to update regulations as new technologies make more efficient precautions available at lower cost. By contrast, "reasonableness" automatically changes as better technology becomes available. The politi-

${ }^{150}$ See id at $\S \S 288 \mathrm{C}, 295 \mathrm{~A}$. See also The T.J. Hooper, $60 \mathrm{~F} 2 \mathrm{~d} 737,740$ (2d Cir 1932) (opinion by Hand) ("Courts must in the end say what is required [to avoid negligence]."). Ironically, Judge Hand also suggested that custom could supplant the cost-benefit analysis of negligence. See Carroll Towing, 159 F2d at 173.

${ }^{151}$ See Ausness, $55 \mathrm{Md} \mathrm{L} \mathrm{Rev} \mathrm{at} \mathrm{1214-17} \mathrm{(cited} \mathrm{in} \mathrm{note} \mathrm{147).} \mathrm{Presumably,} \mathrm{a} \mathrm{regulatory}$ compliance defense would not apply to safety regulations that were not intended to approximate a reasonable level of care. See Henderson, 56 NC L Rev at 638-40 (cited in note 147). Many federal regulations, however, would meet this criteria. Ausness, $55 \mathrm{Md} \mathrm{L}$ Rev at 1214-17 (cited in note 147).

${ }^{152}$ See Ausness, $55 \mathrm{Md}$ L Rev at 1238 (cited in note 147); Clayton P. Gillette and James E. Krier, Risk, Courts, and Agencies, 138 U Pa L Rev 1027, 1064-69 (1990) (analyzing the problem of industry "capture" of a regulatory agency); Richard B. Stewart, The Reformation of American Administrative Law, 88 Harv L Rev 1667, 1682-88 (1975) (documenting widespread popular fear of industry "capture" phenomenon).

${ }^{153}$ See Ausness, 55 Md L Rev at 1238 (cited in note 147); Susan Rose-Ackerman, Progressive Law and Economics-And the New Administrative Law, 98 Yale L J 341, 361-63 (1988) (documenting the compromises made in propounding OSHA standards).

${ }^{13}$ See Thomas 0 . McGarity, Reinventing rationality: The role of regulatory analysis in the federal bureaucracy 126-42 (Cambridge 1991). 
cal and economic realities of agency functions mean that a strong regulatory compliance defense risks freezing safety at potentially inadequate levels of precautions, which become increasingly inadequate as technology improves. ${ }^{155}$

Federalism also cautions against widespread use of the regulatory compliance defense. Federal law is the source of many safety regulations, whereas state law governs common law tort liability. ${ }^{156}$ The violation of a safety regulation constitutes negligence per se, ${ }^{157}$ but state courts are free to find a defendant who has complied with federal safety regulations negligent. Thus, the effect of the federal regulation is to set a floor on safety-state laws may require a defendant to undertake even more precautions in order to avoid liability. If regulatory compliance determines liability, however, then federal law would completely usurp state tort law. Consequently, the decision as to whether compliance with a safety regulation should be a complete defense to a state tort action requires attention to the appropriate balance between the state and federal governments, ${ }^{158}$ rather than to the advantages of an ex ante norm as opposed to an ex post judgment.

Compliance with custom is also a problematic defense. Customary practices do not necessarily incorporate a reasonable level of care. ${ }^{159}$ They simply might reflect a habit or even result "from the kind of inadvertence, carelessness, indifference, cost-paring and corner cutting that is normally associated with negligence. ${ }^{\$ 160}$ In some situations, however, an industry or profession faces strong incentives to develop customs that represent an accurate ex ante assessment of reasonable care. For example, even without tort liability, manufacturers are likely to build safety precautions into their products, because "[c]ustomers should be willing to pay higher prices for the industry's product or service up to the point where the last dollar spent buys just one dollar in accident cost reduction." ${ }^{\text {161 }}$ Treating compliance with custom as a complete defense to liability would avoid the hindsight bias. The courts, however, want to avoid inefficient customs. In the famous case of The

${ }^{155}$ See Ausness, $55 \mathrm{Md} \mathrm{L}$ Rev at 1238 (cited in note 147).

${ }^{156}$ See Erie Railroad Co $v$ Tompkins, 304 US 64, 99-100 (1938).

${ }^{157}$ See Restatement (Second) of Torts $\$ 288 B$.

${ }^{2 s 8}$ See Ausness, 55 Md L Rev at 1237-38 (cited in note 147); Stephen A. Gardbaum, The Nature of Preemption, 79 Cornell L Rev 767, 804-12 (1994) (analyzing the federalism issues relating to the preemption of tort claims).

${ }^{159}$ See Eric Posner, Law, Economics, and Inefficient Norms, 144 U Pa L Rev 1697, 1705-10 (1996) (arguing that social norms have a tendency to generate inefficiency).

${ }^{160}$ Keeton, et al, Prosser on Torts $\$ 33$ at 194 (cited in note 82).

${ }^{161}$ R. Posner, Economic Analysis of Law at 168 (cited in note 6). 
T.J. Hooper, ${ }^{162}$ Judge Learned Hand held that a tug company's failure to carry a radio on board could have been negligent, even though, by custom, tugs at the time did not carry radios. ${ }^{163}$ Judge Hand worried that "a whole calling may have unduly lagged in the adoption of new and available devices."164 Judge Hand ruled that although an industry custom is relevant to a determination as to whether a defendant was negligent, a court could find that a defendant who complied with a custom was nevertheless negligent. ${ }^{165}$ This holding and its eventual success in the common law ${ }^{166}$ suggest that, at least as to custom, the courts have failed to recognize the limitations of second-guessing an ex ante norm after an adverse event occurs.

Judicial skepticism of industry custom, however, probably results from the limits of custom, rather than from ignorance of the hindsight bias. Judge Posner's assertion that customers will pressure manufacturers to offer products with efficient levels of safety precautions depends upon a number of assumptions. An efficient custom is only likely to develop if the transaction costs between the entity that provides the product or service and everyone who may be injured by the product or service are low. ${ }^{167}$ Even if transaction costs are low, an efficient custom also requires that customers have the same bargaining power, ability to identify efficient precautions, and risk preferences as the entity providing the good or service. ${ }^{168}$ Few transactions have such characteristics and these transactions will be rare and hard to identify. Consequently, the cautious approach to custom that the courts have followed makes economic sense. Furthermore, economic consequences aside, courts may simply be unwilling to allow the ap-

\footnotetext{
${ }^{102} 60$ F2d 737, 740 (2d Cir 1932).

${ }^{105}$ But see Epstein, $21 \mathrm{~J}$ Legal Stud at 32-36 (cited in note 147) (arguing that the custom at the time favored the use of radios).

${ }^{16}$ The T.J. Hooper, $60 \mathrm{~F} 2 \mathrm{~d}$ at 740 . Law and economics scholars have questioned the merits of this suggestion. Professor Epstein refers to this assertion as "perhaps the most influential, and mischievous, sentence in the history of the law of torts." Epstein, $21 \mathrm{~J} \mathrm{Le-}$ gal Stud at 38 (cited in note 147).

${ }^{165}$ The T.J. Hooper, 60 F2d at 740.

${ }^{168}$ The rule that custom is relevant to the determination of negligence but is not controlling has been adopted into the Restatement (Second) of Torts $\$ 295 \mathrm{~A}$ and is followed in a majority of jurisdictions. Epstein, $21 \mathrm{~J}$ Legal Stud at 38 (cited in note 147). A small minority of jurisdictions defer completely to custom and another small minority treat evidence of custom as irrelevant. Id at 17-32.

${ }^{167}$ See Landes and R. Posner, The Economic Structure of Tort Law at 132-33 (cited in note 108); R. Posner, Economic Analysis of Law at 168 (cited in note 6).

${ }^{168}$ See James A. Henderson, Jr. and John A. Siliciano, Universal Health Care and the Continued Reliance on Custom in Determining Medical Malpractice, 79 Cornell L Rev $1382,1389-95$ (1994) (arguing that the complexity of medical practice and the ignorance of patients challenge the wisdom of relying on custom).
} 
parent negligence of everyone in a profession to absolve a single member of fault. ${ }^{169}$

In one class of cases-medical malpractice-courts have acknowledged that the profession's ex ante custom is probably superior to their ex post judgment. ${ }^{170}$ Doctors who have followed customary medical procedure are not to be considered negligent. ${ }^{171}$ The courts believe that the conditions necessary for the development of efficient customs exist in the medical profession. ${ }^{172}$ This exception to the general rule shows that the courts do distrust the value of second-guessing ex ante decisions. However, there are reasons other than the hindsight bias to treat a medical custom as reasonable per se. The medical profession has more expertise than the courts at determining appropriate treatments ${ }^{173}$ and has sufficient economic incentives to develop customs that reflect due care. ${ }^{174}$ The inaccuracy of judging in hindsight is yet another strike against the institutional competence of the courts.

The refusal to rely more heavily on either regulatory compliance or custom presents a lost opportunity to avoid a biased as-

${ }^{10}$ See Keeton, et al, Prosser on Torts $\S 33$ at $194-95$ (cited in note 82).

${ }^{270}$ See Landes and R. Posner, Economic Structure of Tort Law at 137 (cited in note 108); Keeton, et al, Prosser on Torts $\S 32$ at 189 (cited in note 82). Other professionals are liable if their conduct fails to conform to that of a "reasonable" member of the profession, see Keeton, et al, Prosser on Torts $\S 24$ at 145, leaving them subject to the hindsight bias. In a medical malpractice case in which there is no relevant custom, a determination of liability would be influenced by the hindsight bias as well.

${ }^{171}$ See, for example, Hood v Phillips, 554 SW2d 160, 165 (Tex 1977) ("A physician who undertakes a mode or form of treatment which a reasonable and prudent member of the medical profession would undertake ... shall not be subject to liability."). But see Helling $v$ Carey, 83 Wash 2d 514, 519 P2d 981, 983 (1974) (finding an opthamologist liable for failing to give a glaucoma test to a young plaintiff, even though medical practice opposed giving the test). The case is probably a rare exception to the general rule that adherence to customary treatments cannot be negligent. See Neil Meltzer, Comment, Helling v. Carey: Landmark or Exception in Medical Malpractice, 11 New Eng L Rev 301, 303-07 (1975). Curiously, the Helling case is one in which medical custom was not supported by a costbenefit analysis. See William B. Schwartz and Neil K. Komesar, Doctors, Damages, and Deterrence: An Economic View of Medical Malpractice, 298 New Eng J Med 1282, 1283 (1978) (concluding that under the circumstances in the case, a glaucoma test cost $\$ 5$, but saved $\$ 27$ in expected losses). The court, in Helling, did not rely on this cost-benefit analysis, but, had it done so, it would have been able to rely on fairly precise ex ante estimates for costs and benefits rather than subjective ones. This might have enabled it to avoid the hindsight bias. To the extent that any ambiguity in ex ante estimates exists, however, the hindsight bias would probably re-emerge as an influence on judgment.

${ }^{172}$ See R. Posner, Economic Analysis of Law at 168-69 (cited in note 6). But see Henderson and Siliciano, 79 Cornell L Rev at 1389-1400 (cited in note 168) (arguing that courts' assumption that appropriate custom will develop in medical practice may be incorrect).

${ }^{173}$ See Keeton, et al, Prosser on Torts $\$ 33$ at 192-95 (cited in note 82).

${ }^{174}$ See R. Posner, Economic Analysis of Law at 169 (cited in note 6). 
sessment of liability, especially in the case of custom. ${ }^{175}$ Professor Epstein and Judge Posner have argued that, in circumstances in which custom is likely to reflect reasonable care, allowing courts to make their own judgments can only lead to wasteful mistakes. ${ }^{176}$ Analysis of the hindsight bias shows that the situation is even worse than that; a defendant who has followed industry custom is likely to be found liable, especially because customs probably do not incorporate an excess of care. ${ }^{177}$ There are, however, good reasons to suppose that regulations and customs might not actually reflect an appropriate analysis of reasonable precautions. Where there is strong reason to believe that the ex ante norm is identical to reasonable care, as in the case of medical malpractice, the courts have relied on it as a gauge of negligence that is superior to their ex post judgments. Furthermore, treating compliance with regulation or custom as relevant evidence of reasonable care might mitigate some of the hindsight bias's impact on the negligence determination. In effect, the common law does the best that it can in response to the fallibility of judging in hindsight and the inadequacy of custom and regulation as substitutes for ex ante assessments of reasonable care.

\section{Good evidence of an ex ante assessment: the case of patent law.}

Hindsight problems are not restricted to the common law. The federal courts, for example, have long struggled with the problem of judging the validity of patents in hindsight and have worked to develop a sensible resolution to the hindsight bias. For a device or technique to merit patent protection, it must not only be novel and useful, it must actually be an invention-it must be a "nonobvious" advance in an art. ${ }^{178} \mathrm{~A}$ patent requires more "skill and ingenuity" than that possessed by an "ordinary mechanic acquainted with the business."179 Congress codified this requirement in 1952:

\footnotetext{
${ }^{175}$ Although he was not referring to the hindsight bias, Professor Henderson remarked that "to reject the use of ... [safety] regulations as a standard ... is to miss an important opportunity to render more consistent and rational the patterns of decisions in many product areas." Henderson, 56 NC L Rev at 639 (cited in note 147).

${ }^{126}$ Epstein, $21 \mathrm{~J}$ Leg Stud at 38 (cited in note 147); R. Posner, Economic Analysis of Law at 168 (cited in note 6).

${ }^{17}$ Competitive pressures would likely keep the industry from taking more precautions than they need to avoid liability.

${ }^{273}$ See Ernest Bainbridge Lipscomb III, Libscomb's Walker on Patents $\$ 6.1$ at 4 (Law Co-op 3d ed 1985).

${ }^{170}$ Hotchkiss $v$ Greenwood, 52 US (11 How) 248, 267 (1850). For example, the patent at issue in Hotchkiss was for a ceramic doorknob. The Court deemed this an obvious innova-
} 
A patent may not be obtained ... if the differences between the subject matter sought to be patented and the prior art are such that the subject matter as a whole would have been obvious at the time the invention was made to a person having ordinary skill in the art to which said subject matter pertains. ${ }^{180}$

According to the Supreme Court, to determine nonobviousness, "the scope and content of the prior art are to be determined; differences between the prior art and the claims at issue are to be ascertained; and the level of ordinary skill in the pertinent art resolved. ${ }^{181}$ In short, nonobviousness depends upon whether the "invention" represents a technological advance "beyond the skill of the calling. ${ }^{m 182}$

The determination of nonobviousness is likely to be affected by the hindsight bias, although this has not been tested empirically. ${ }^{183}$ Even a truly novel idea might seem obvious after it has been revealed. The law requires that nonobviousness be determined "at the time the invention was made," although "hindsight is often difficult to avoid in determining obviousness of inventions." ${ }^{\text {185 }}$ Courts have recognized the problem of hindsight and have expressed concern that they "must be continually on guard against the natural tendency to treat as obvious something which appears simple in the light of hindsight, but which may not actually have been so at the time of the invention."

Partly in response to the influence of hindsight, the Supreme Court added "secondary considerations" to the test for nonobviousness. In addition to the inquiry into the technical aspects of the invention, the Court also requires lower courts to analyze

tion. Id.

${ }^{180} 35$ USC $\$ 103(a)$ (1994) (emphasis added).

${ }^{181}$ Graham v John Deere Co, 383 US 1, 17 (1966).

${ }^{182}$ Id at $15 \mathrm{n} 7$.

${ }^{183}$ See the discussion of the hindsight bias and foreseeability in Part II.B.3.

${ }^{264} 35$ USC $\S 103(a)$.

${ }^{165}$ Ellicott Machine Corp $v$ United States, 405 F2d 1385, 1390 (Ct Cl 1969).

${ }^{166}$ Teleflex Inc v American Chain \& Cable Co, 273 F Supp 573, 587 (S D NY 1967). See also Kaz Manufacturing Co $v$ Northern Electric Co, 412 F Supp 470, 484 (S D NY 1976) (referring to hindsight as "convenient but misleading"); Borden, Inc $v$ Occidental Petroleum Corp, 381 F Supp 1178, 1205 (S D Tex 1974) ("Obviousness can[not] . . . be resolved through ... analysis distorted by ... retrospective self-evidence or hindsight."); Erie Technological Products, Inc v Die Craft Metal Products, Inc, 318 F Supp 933, 936 (N D Ill 1970), modified on other grounds, 461 F2d 5 (7th Cir 1972) ("In determining whether a patent is invalid for obviousness, a court must guard against . . . slipping into hindsight."). The most extreme statement on hindsight was made in Ransburg Electro-Coating Corp $v$ Nordson Corp, 293 F Supp 448, 482 (N D III 1968) ("[H]indsight is of no value in determining what would have been obvious at the time the invention was made."). 
"such secondary considerations as commercial success, long felt but unsolved need, failure of others, etc., [that] might be utilized to give light to the circumstances surrounding the origin of the subject matter sought to be patented. ${ }^{\text {187 }}$ The Court observed that determining nonobviousness by reference to these secondary considerations helps courts avoid conducting a technical inquiry that they might be incompetent to undertake, and "guard[s] against slipping into the use of hindsight." ${ }^{n 188}$ The mere fact of an invention will not color a court's evaluation of the evidence of the invention's commercial success or its resolution of a long-felt unresolved need, whereas the mere fact of the invention might make the inventor's technical achievements seem obvious. Secondary characteristics have grown in importance since the Court first introduced them into the test for nonobviousness. The Federal Circuit ultimately held that an inquiry into secondary characteristics may, by itself, support the conclusion that an invention was not obvious. ${ }^{189}$ Thus, rather than make a technical evaluation of how the inventor arrived at his or her alleged innovation, courts determining nonobviousness may look to considerations that are not as susceptible to the hindsight bias. ${ }^{190}$

The situation here resembles medical malpractice. Part of the reason that courts rely on custom in medical malpractice and secondary evidence of nonobviousness in patent law is a recognition of their limited ability to understand technical or scientific subject matters raised by such cases, but the courts also recognize that judgments made in hindsight are biased. ${ }^{191}$ The law, in both cases, represents an attempt to find reliable ex ante evidence of an appropriate judgment, so that trial courts need not rely on judgments made in hindsight that are influenced by outcome knowledge.

\section{No "liability by hindsight."}

Although no general remedy for the hindsight bias is available, courts have used the burden of production to blunt the bene-

${ }^{187}$ Graham, 383 US at 17-18.

${ }^{188}$ Id at 36, quoting Monroe Auto Equipment Co $v$ Heckthorn Manufacturing \& Supply Co, 332 F2d 406, 412 (6th Cir 1964).

${ }^{180}$ Vandenberg $v$ Dairy Equipment Co, 740 F2d 1560, 1567 (Fed Cir 1984).

${ }^{10}$ See Dorothy Whelan, Note, $A$ Critique of the Use of Secondary Considerations in Applying the Section 103 Nonobviousness Test for Patentability, 28 BC L Rev 357, 360-65 (1987) (discussing the case law and questioning the use of certain secondary characteristics).

${ }^{191}$ The bias is especially pernicious in an unfamiliar context. See ChristensenSzalanaski and Willham, 48 Org Beh \& Human Decision Processes at 154-55 (cited in note 2). 
fit that the hindsight bias confers upon plaintiffs in negligence cases. Because of the bias, a plaintiff could rely exclusively on the mere fact of an adverse outcome to convince a judge or jury that the defendant's actions were negligent. To prevent this possibility, courts require more evidence than the mere fact of injury. ${ }^{192}$ As the Oregon Supreme Court described this doctrine: "With hindsight's $20 / 20$ vision, it is easy to see that [the defendant] should have foreseen ... a risk to the public at large. [But, p]roof aided by hindsight . . . is insufficient to establish negligence. ${ }^{\$ 193}$ As a general matter, "[t]he mere fact that an accident or an injury has occurred, with nothing more, is not evidence of negligence on the part of anyone." 194

The federal courts have adopted a particularly vigorous prohibition against liability based solely on hindsight in cases alleging violations of the federal securities laws. ${ }^{195}$ To win a federal securities case, a plaintiff must allege and prove that a defendant has intentionally misrepresented material facts about a publicly traded company in an effort to defraud investors. ${ }^{196}$ As in all fraud cases, in order to survive a motion to dismiss brought under Rule 9(b), plaintiffs must make additional allegations of specific instances of intended fraud. ${ }^{197}$ Courts have held that, in a case of alleged securities fraud, this heightened pleading requirement means that a plaintiff must do more than merely allege that some

${ }^{192}$ See Keeton, et al, Prosser on Torts $\$ 39$ at 242 (cited in note 82 ). In cases in which the doctrine of res ipsa loquitur is applicable, however, the plaintiff need only demonstrate that an adverse outcome occurred. See Restatement (Second) of Torts $\S 328 D$; Keeton, et al, Prosser on Torts $\S 39$ at 242 (cited in note 82).

${ }^{193}$ Cain v Rijken, 300 Or 706, 720, 717 P2d 140, 149 (1986).

${ }^{194}$ Keeton, et al, Prosser on Torts $\$ 39$ at 242 (cited in note 82 ).

${ }^{195}$ Securities Act of 1933, Pub L No 73-38, 48 Stat 74, codified at 15 USC $\$ \S 77 \mathrm{a}-77 \mathrm{z}$ (1994); Securities Exchange Act of 1934, Pub L No 73-404, 48 Stat 881, codified at 15 USC $\$ \S 78 a-7811$ (1994). See D. Brian Hufford, Deterring Fraud vs. Avoiding the "Strike Suit": Reaching an Appropriate Balance, 61 Brooklyn L Rev 593, 605-06 (1995) ("Courts have been especially aggressive in dismissing cases that merely plead 'fraud by hindsight." ); Robert A. Prentice and John H. Langmore, Beware of Vaporware: Product Hype and the Securities Fraud Liability of High-Tech Companies, 8 Harv J L \& Tech 1, 25 (1994) ("Courts generally have been careful to prevent plaintiffs from alleging 'fraud by hindsight.").

${ }^{196}$ See Basic, Inc $v$ Levinson, 485 US 224, 231 (1988) (stating the elements of a violation of Section 10(b) of the Securities Exchange Act of 1934).

${ }^{197}$ FRCP 9(b). This Rule requires that a complaint alleging fraud must describe the particular circumstances of the alleged fraud. See Charles A. Wright and Arthur L. Miller, 5 Federal Practice and Procedure 1297 (West 1990). Rule 9(b) has been used extensively in federal securities cases. See Alexander, $43 \mathrm{Stan} L \mathrm{Rev}$ at 524-28 (cited in note 93). Since few of these cases go to trial, the merits of these cases are fought in pre-trial motion practice. See id. As a consequence, the "fraud-by-hindsight" doctrine is raised earlier in securities cases than it would be in a tort suit. For example, note that the prohibition against relying exclusively on hindsight in Cain, 717 P2d at 142, arose in the context of a summary judgment motion. 
prediction made by the defendant ultimately failed to come true. ${ }^{198}$ "There is no 'fraud by hindsight."1199 However, plaintiffs who can allege specific circumstances of fraud in addition to the defendants' failed predictions still benefit from the courts' judging in hindsight. ${ }^{200}$ The "fraud by hindsight" doctrine guards only against a severe abuse of the hindsight bias; it does not entirely purge the system of the bias's influence.

\section{Subsequent remedial measures.}

Although suppressing evidence is not generally a useful way to avoid the influence of the hindsight bias, courts can sometimes suppress evidence that would, if admitted, exacerbate the bias's impact on the judgment. For example, the rule that a defendant's post-accident remedial measures are not admissible to prove negligence ${ }^{201}$ can be traced to the hindsight bias. Injurers often update their safety precautions after an accident, and wisely so. An accident can teach an injurer much about how to avoid causing future harm. Nevertheless, such subsequent remedial measures are almost irrelevant to a determination as to whether the defendant was negligent with respect to the initial accident. ${ }^{202}$ These measures only reveal insights gleaned from the adverse outcome itself and do not speak to what was predictable beforehand.

The liberal rules of relevance in contemporary evidence law, however, probably support admitting evidence that a defendant has taken subsequent remedial measures. ${ }^{203}$ Defendants should,

${ }^{\infty}$ See William S. Feinstein, Pleading Securities Fraud With Particularity-Federal Rule of Civil Procedure 9(b) in the Rule 10b-5 Context: Kowal v. MCI Communications Corporation, 63 Geo Wash L Rev 851, 857-58 (1995) (noting courts' reluctance to admit "fraud by hindsight" without supporting evidence); Elliott J. Weiss, The New Securities Fraud Pleading Requirement: Speed Bump or Road Block?, 38 Ariz L Rev 675, 684 (1996) (discussing whether requiring that fraud be plead with particularity deters "fraud by hindsight" claims).

${ }^{199}$ Dileo $v$ Ernst \& Young, 901 F2d 624, 628 (7th Cir 1990), quoting Denny v Barber, 576 F2d 465, 470 (2d $\mathrm{Cir} 1978$ ) (opinion by Friendly).

${ }^{200}$ This assumes that the hindsight bias implicates subjective standards. See discussion in Part II.B.2.

${ }^{201}$ See FRE 407; David P. Leonard, Selected Rules of Limited Admissibility, The New Wigmore $\S \S 2.3 .4,2.5$ (Little, Brown 1996) (Only two states, Maine and Rhode Island, regularly admit such evidence to prove negligence.). Subsequent remedial measures are admissible for other purposes, "such as proving ownership, control, or feasibility of precautionary measures, if controverted, or impeachment." FRE 407.

${ }^{202}$ The relevance of subsequent remedial measures to negligence has been a point of some debate, but the debate is about whether they are relevant at all. See Leonard, Selected Rules of Limited Admissibility at $\$ \S 2.2,2.3 .1$ (providing an account of both sides of the argument).

${ }^{200}$ See FRE 407 Advisory Committee's Note (Adopting a subsequent remedial measure 
in principle, have no fear of this evidence. If the evidence that the defendant took subsequent remedial measures is virtually irrelevant, then a rational factfinder should give it no weight. The evidence should have no effect on the outcome.

Nevertheless, courts have worried that evidence that the defendant has taken subsequent remedial measures will have a dramatic effect on a jury. ${ }^{204}$ They worry that juries will mistakenly assume that "because the world gets wiser as it gets older, therefore it was foolish before. ${ }^{3205}$ This is essentially an assertion that juries' assessments of defendants' adoption of subsequent remedial measures will be influenced by the hindsight bias. If juries do overreact to the defendant taking subsequent remedial measures, then defendants will be loath to undertake them. The increased probability of paying for the accident that already occurred might overwhelm the benefits to the defendant of reducing the prospects of future liability, at least until the trial is over. Courts worry that admitting evidence of subsequent remedial measures would induce juries to hold defendants liable when they actually took reasonable care. This would discourage defendants from taking subsequent remedial measures. To avoid this problem, courts have deemed such evidence inadmissible. ${ }^{206}$

In cases involving subsequent remedial measures, the courts suppress evidence that would magnify the hindsight bias's influence on the judgment, thereby averting an unwanted incentive structure. Admitting such evidence would not only leave the defendant subject to the ordinary version of the hindsight bias-the accident occurred, so the defendant's actions appear less reasonable than they would in foresight-but it also would tempt the jury with more detailed evidence of the consequences of the defendant's initial decision. The fact of the accident cannot realistically be suppressed, but evidence that would aggravate the bias can be. Courts' response to the problem of subsequent remedial measures reveals a good understanding of the hindsight bias and the judicial ability to respond to it.

\footnotetext{
"is not in fact an admission" of fault, but "[u]nder a liberal theory of relevancy, this ground alone would not support exclusion as the inference is still a possible one.").

${ }^{20}$ See Leonard, Selected Rules of Limited Admissibility $\S 2.2$ at 2-14 (cited in note 201).

${ }^{200}$ Hart $v$ The Lancashire \& Yorkshire Railway Co, 21 LTR (ns) 261, 263 (Exch 1869).

${ }^{206}$ See, for example, Flaminio $v$ Honda Motor Co, 733 F2d 463, 471 (7th Cir 1984) (opinion by Posner) ("It is only because juries are believed to overreact to evidence of subsequent remedial measures that the admissibility of such evidence could deter defendants from taking such measures.").
} 


\section{Adopting a "No Liability" Rule}

The courts have thus proven remarkably adept at pursuing opportunities to avoid or reduce the impact of the hindsight bias on judgments of liability. These opportunities are restricted to isolated circumstances, however, and the lack of a generally applicable remedy leaves a great many cases subject to the bias's influence. In some circumstances, the adverse consequences of biased judgments are both unavoidable and intolerable. In these situations, rather than subject defendants to biased judgments of liability, the best option might be to refuse to hold defendants liable - even if their actions seem negligent in hindsight. A rule of "no liability" might have fewer adverse consequences than a rule of negligence judged in hindsight. Indeed, in certain situations, courts have adopted just such a rule.

The best example of such a situation is probably the business judgment rule in corporate law. The business judgment rule refers to the standard for judicial review of decisions by corporate officers and directors. ${ }^{207}$ The rule varies across jurisdictions ${ }^{208}$ and is difficult to state precisely, ${ }^{209}$ but an officer or director who is informed about a transaction being undertaken by the corporation, and is not an interested party in the transaction, "fulfills his duty [of care to the shareholders] if . . . he rationally believes that his business judgment is in the best interests of the corporation. ${ }^{.210}$ Officer and directors who satisfy the elements of the rule ${ }^{211}$ are

${ }^{207}$ See Dennis J. Block, Nancy E. Barton, and Stephen A. Radin, The Business Judgment Rule: Fiduciary Duties of Corporate Directors and Officers 3-4 (Prentice Hall 2d ed 1988).

See E. Norman Veasey and Julie M.S. Seitz, The Business Judgment Rule in the Revised Model Act, The Trans Union Case, and the American Law Institute Project-A Strange Porridge, 63 Tex L Rev 1483, 1484-97 (1985) (discussing different formulations of the business judgment rule).

${ }^{200}$ See Franklin A. Gevurtz, The Business Judgment Rule: Meaningless Verbiage or Misguided Notion?, $67 \mathrm{~S} \mathrm{Cal} \mathrm{L} \mathrm{Rev} \mathrm{287,} 289$ (1994) ("Defining the business judgment rule is no easy task.").

${ }^{210}$ American Law Institute, Principles of Corporate Governance: Analysis and Recommendations $\S 4.01$ (c) at 177-78 (ALI 1991). The hindsight bias might affect the ex post assessment of whether a decision was "rational." However, the standard of liability under the business judgment rule is so low that even judgments in hindsight are unlikely to ever lead to a finding of liability under this standard.

${ }^{211}$ The basic elements of the business judgment rule are: (1) business decision, (2) disinterest and independence, (3) due care to make an informed choice, (4) no bad faith, and (5) no abuse of discretion. See Block, Barton, and Radin, The Business Judgment Rule at 12-22. The rule of course supplies no protection otherwise. Id at 12. See also Joy $v$ North, 692 F2d 880, 886 (2d Cir 1982) ("The business judgment rule . . . does not apply in cases, e.g., in which the corporate judgment lacks a business purpose, is tainted by conflict of interest, .... is so egregious as to amount to a no-win decision, ... . or results from obvious and prolonged failure to exercise oversight or supervision."). 
not liable to the shareholders for decisions that turn out badlyeven if these decisions seem negligent in hindsight." "Whereas automobile drivers who make a mistake in judgment . . . will likely be called upon to respond in damages, a corporate officer who makes a mistake in judgment . . . will rarely, if ever, be found liable for damages suffered by the corporation." ${ }^{213}$ Under the business judgment rule, "director liability is predicated upon concepts of gross negligence."214 Even "gross negligence" is a somewhat more stringent standard of review than courts commonly use to scrutinize business decisions; ${ }^{215}$ many courts have adopted standards that are even more deferential to the decisions of corporate managers. ${ }^{216}$

But is judicial deference to business decisions attributable to the hindsight bias? There are several justifications for the rule, but the principal ones boil down to the relative institutional competence of corporate managers as compared to the courts. ${ }^{217}$ Corporate managers have much more expertise than courts at making business decisions ${ }^{218}$-a justification that has nothing to do

${ }^{212}$ See, for example, Louisiana World Exposition v Federal Insurance Co, 864 F2d 1147, 1151 (5th Cir 1989) ('Simple negligence alone is insufficient for a finding of personal liability of an officer or director to the corporation."); Joseph W. Bishop, Jr., Sitting Ducks and Decoy Ducks: New Trends in the Indemnification of Corporate Directors and Officers, 77 Yale L J 1078, 1099 (1968) ("The search for cases in which directors of industrial corporations have been held liable in derivative suits for negligence uncomplicated by selfdealing is a search for a very small number of needles in a very large haystack.").

${ }^{213}$ Joy, 692 F2d at 885 (citations omitted).

${ }^{214}$ Aronson $v$ Lewis, 473 A2d 805, 812 (Del 1984).

${ }^{215}$ See Block, Barton, and Radin, The Business Judgment Rule at 63-64 (cited in note 207).

${ }^{216}$ See, for example, Gearhart Industries, Inc $v$ Smith International, Inc, 741 F2d 707, 721 (5th $\mathrm{Cir} 1984$ ) ("Texas courts . . . will not impose liability upon a noninterested corporate director unless the challenged action is ultra vires or tainted by fraud."). See also Marcia M. McMurray, Note, A Historical Perspective on the Duty of Care, the Duty of Loyalty, and the Business Judgment Rule, 40 Vand L Rev 605, 614-16 (1987) (discussing various standards). The standard of review for "gross negligence" likewise applies only to the decisionmaking process, not to the substantive decision, which receives more deferential treatment. See Veasey and Seitz, 63 Tex L Rev at 1486-87 (cited in note 208). The Delaware legislature was even unhappy with the "gross negligence" standard. After the Delaware Supreme Court adopted the "gross negligence" standard in Aronson, 473 A2d at 812, and Smith $v$ Van Gorkom, 488 A2d 858, 873 (Del 1985), the legislature lowered the standard so as to give corporate managers even more discretion. See Arkes and Schipani, 73 Or L Rev at 618 (cited in note 8).

${ }^{217}$ Other justifications include the effort to promote managerial control over shareholder control of the corporation and the relatively unsympathetic position of the shareholders, who are usually free to dispose of their ownership interest in the corporation if they feel that the management is incompetent. See Block, Barton, and Radin, The Business Judgment Rule at 7-11 (cited in note 207); McMurray, 40 Vand L Rev at 616-17; Ralph A. Peeples, The Use and Misuse of the Business Judgment Rule in the Close Corporation, 60 Notre Dame L Rev 456, 483-85 (1985).

${ }^{218}$ See Auerbach $v$ Bennett, 47 NY2d 619, 630, 419 NYS2d 920, 926, 393 NE2d 994, 
with the hindsight bias. Expertise, however, is not a sufficient account of the business judgment rule; the courts have no problem holding other experts, such as lawyers and accountants, liable for negligent decisions. ${ }^{219}$ Courts evaluating business decisions also mistrust their perspective:

[C]ourts recognize that after-the-fact litigation is a most imperfect device to evaluate corporate business decisions. The circumstances surrounding a corporate decision are not easily reconstructed in a courtroom years later . . . . [A] reasoned decision at the time made may seem a wild hunch viewed years later against a background of perfect knowledge. ${ }^{220}$

The business judgment rule arises from the concern that even a good decision can produce an undesirable result and can be judged unfairly in hindsight. "Courts recognize that even disinterested, well-intentioned, informed directors can make decisions that, in hindsight, were improvident."221

This rationale, however, also applies to potential tort defendants, especially in cases of professional liability. ${ }^{222}$ Indeed, the similarities between corporate managers and other professionals are striking. ${ }^{223}$ All professionals could merit deference from judicial second-guessing of their decisions, particularly as this second-guessing is done in hindsight. Nevertheless, both equitable and economic factors provide grounds for distinguishing the business judgment context from other professional liability. Immunizing professionals from liability for negligence would create a greater injustice for potential plaintiffs than the business judgment rule inflicts upon shareholders. Shareholders can fire incompetent managers either directly through a shareholder vote, or indirectly by selling their holdings in the corporation. ${ }^{224} \mathrm{Al}$ -

1000 (1979) ("The business judgment doctrine, at least in part, is grounded on the prudent recognition that courts are ill equipped ... to evaluate what are and must be essentially business judgments."); Joseph Hinsey, IV, Business Judgment and the American Law Institute's Corporate Governance Project: the Rule, the Doctrine, and the Reality, 52 Geo Wash L Rev 609, 612 (1984) (recognizing the courts' tendency to defer to managerial discretion).

${ }^{219}$ See, for example, Gevurtz, $67 \mathrm{~S}$ Cal L Rev at 305 (cited in note 209). Courts do defer somewhat to doctors by allowing a defense based on compliance with customary medical practice. See Part IV.B.1.

200 Joy, 692 F2d at 886.

${ }^{221}$ Washington Bancorp v Said, 812 F Supp 1256, 1267-68 (D DC 1993).

${ }^{22}$ See Arkes and Schipani, 73 Or L Rev at 621-29 (cited in note 8) (comparing the liability of corporate managers to doctors).

${ }^{25}$ See Gevurtz, 67 S Cal L Rev at 288 (cited in note 209) (using these similarities to extend Judge Hand's cost-benefit analysis for negligence to business decisions).

${ }^{22}$ See Peeples, 60 Notre Dame L Rev at 461 (cited in note 217) ("Courts have deferred 
though patients and clients can fire incompetent lawyers or accountants, the harm that is inflicted in the meantime may be more personally significant. ${ }^{225}$ Incompetent managers will only cost shareholders their money, after all. To be sure, this distinction is a slight over-generalization-the loss of a personal investment in a business could exceed the financial loss from legal or accounting malpractice. ${ }^{226}$ Shareholders, however, can diversify their risk of loss in a manner that is not possible in the professional service context. ${ }^{27}$ The likely nature of the damages in each context distinguishes corporate liability from the liability of other professionals.

Economic grounds provide a better explanation for the different liability standards in corporate governance as opposed to other professions. The bias converts the negligence standard into a quasi-strict liability rule, which if applied to corporate managers would either induce them to take an excess of precautions or to act as if they operated under a system of strict liability. If it mimicked strict liability, then fewer people would be willing to become corporate managers than if they were subject to an unbiased negligence system. ${ }^{228}$ This concern might account for the business judgment rule, and it does run through the early business judgment cases in the nineteenth century. ${ }^{229}$

Furthermore, the possibility that quasi-strict liability would create incentives to take an excess of precautions would undermine the basic functioning of corporate managers more severely than other professionals. Investors want corporate managers to make risk-neutral business decisions, because investors already control their overall investment risk through diversification. ${ }^{230}$ Ensuring that managers effectively represent this concern and do not avoid business decisions that have a high expected payoff but also carry a high degree of risk is a central problem of corporate governance. ${ }^{231}$ Liability for negligence judged in hindsight would

to managerial decisions because of the assumption that the shareholder has an alternate course of action: selling the interest in the corporation.").

${ }^{225}$ See Arkes and Schipani, 73 Or L Rev at 623 (cited in note 8).

${ }^{226}$ See Gevurtz, $67 \mathrm{~S}$ Cal L Rev at 312-14 (cited in note 209).

${ }^{27}$ See text accompanying notes 230-31.

${ }^{203}$ This is because even though strict liability and negligence are equally efficient, strict liability may decrease activity levels by placing the entire cost on the potential defendant. R. Posner, Economic Analysis of Law at 175-80 (cited in note 6).

${ }^{229}$ See, for example, Briggs $v$ Spaulding, 141 US 132, 148-49 (1891); Godbold v The Branch Bank, 11 Ala 191, 199 (1847); Percy v Millaudon, 8 Mart (ns) 68, 77-78 (La 1829); Spering's Appeal, 71 Pa 11, 24 (1872); Hodges v New England Screw Co, 1 RI 312, 346-47 (1850).

${ }^{200}$ See Joy, 692 F2d at 886 n 6.

${ }^{231}$ See R. Posner, Economic Analysis of Law at 405 (cited in note 6). 
only exacerbate this problem. Investors do not need the security of being able to hold their managers strictly liable, and they certainly do not want them taking an excess of precautions against losses. As the court in Joy $v$ North ${ }^{232}$ put it: "[I]t is very much in the interests of shareholders that the law not create incentives for overly cautious corporate decisions." We might want lawyers or accountants to guarantee their work with a system of de facto strict liability, or take an occasional excess of precautions, but corporate managers operating under such a regime will be apt to betray the real interests of their shareholders.

Without the hindsight bias, it is difficult to explain why corporate managers are immune from liability for negligence and other professionals are not. Arguably, all professionals have sufficient incentives to avoid negligent conduct-they need to do so in order to retain their patients or clients. Therefore, all professionals could argue that they should be immune from liability for negligent conduct. Alternatively, professionals have much more information than their clients, patients, and shareholders, and are in the best position to reduce the social costs of their actions. Therefore, all professionals (corporate managers included) should be subject to liability. When negligence judged in hindsight is revealed to be a system of quasi-strict liability, however, the distinction becomes clear. Strict liability is a perfectly defensible, even laudable, form of liability-it creates incentives to be efficient and spreads the risk of injury, reducing the possibility that a single individual will experience a catastrophic loss. But adopting a system of strict liability raises the costs of any activity, which might create some unwanted consequences. The consequences of a system of strict liability are particularly undesirable to shareholders in a corporation. Shareholders already spread their risks through diversification and, even without a system of quasi-strict liability, they must worry that their managers make risk-averse decisions. With decades of experience in the matter and a basic understanding of the foibles of judging in hindsight, courts seem to have realized this, and carved out the business judgment rule for corporate managers alone among professionals.

\section{Summary of Adaptations}

Remedies for the hindsight bias are situation specific, but some generalizations can be made. The four specific instances identified in this Article in which courts have developed proce- 
dures to mitigate the impact of the hindsight bias on judgment, along with the development of the business judgment rule, reveal two basic patterns. First, the courts try to keep information that could not have been known ex ante out of the process of ex post judgment. In negligence cases, they suppress evidence of subsequent remedial measures because it reflects the defendant's understanding after an accident, not before. In patent cases, they refrain from reanalyzing the patent's advances and look only to ex ante circumstances such as whether the patent fulfilled a longfelt unresolved need. Second, the law tends to enforce the ex ante understanding between the parties, if there is one. In the case of medical malpractice, the doctor is not a guarantor of recovery. A patient does not purchase a promise of good health, but purchases the "customary" medical treatment. Doctors who fail to deliver the customary treatment have not fulfilled their end of the bargain, and hence are subject to liability. Likewise, investment in a corporation does not guarantee a positive return; it is a gamble on the abilities of the officers and directors of the corporation. The ex ante bargain is only that the management will remain informed and not engage in self-dealing.

The legal system is, in some ways, trapped in a second best world. Judgments tainted by the hindsight bias have costs. They can induce an excess of precautions and smack of unfairness. But the courts have responded to these concerns. They have developed two basic responses-suppressing post-event information and enforcing ex ante arrangements-that are remarkably elegant methods of blunting the impact of the hindsight bias. Although the legal system must tolerate biased judgments, the courts occasionally mitigate their adverse consequences.

\section{CONCLUSION: LIABILITY IN A SYSTEM OF SECOND-BEST JUDGMENTS}

The legal system has a good understanding of the hindsight bias and its effects on judging liability after the fact. Generic debiasing strategies are unlikely to be available and the courts do not attempt to use them. Instead they have developed mechanisms for taking advantage of specific circumstances that allow them to reduce the influence of the hindsight bias. In those cases in which the bias cannot be avoided, the courts have pursued sensible second-best strategies that are sensitive to the consequences of biased judgments for both economics and justice.

The story of the hindsight bias in legal judgments has lessons for legal policymakers. It holds a warning about developing a new area of law that demands a judgment in hindsight. Any 
new area will have to make some accommodation for the bias. For example, in 1983, Rule 11 of the Federal Rules of Civil Procedure was amended to require sanctioning of those who file frivolous lawsuits or motions within a lawsuit. ${ }^{233}$ Frivolousness is difficult to define, ${ }^{234}$ and the 1983 version of the rule couched its definition in terms of reasonableness. ${ }^{235}$ Of course, reasonableness can be determined only after a lawsuit has failed or is dismissed, making it difficult to judge what was reasonable beforehand. It is not clear how the courts have resolved the problems associated with judging litigation in hindsight for frivolousness, but it is safe to say that there has been some dissatisfaction with the 1983 amendments-some of which led to substantial revisions in 1993. ${ }^{236}$ Ultimately, if the federal courts want to sanction frivolous litigation, they will have to devise some means of addressing the problem of judging in hindsight, as they have in many other areas of law.

The development of rules on judging liability in hindsight speaks to two different schools of legal theory-law and economics and law and psychology. To the law and economics community, especially those developing positive theories of law, it shows not only that a cognitive bias can persist in the system, but that the system itself can recognize the bias and adapt to it. In fact, a legal academic armed with an understanding of the limits of human judgment is in a better position to explain the pattern of case law than one without such an understanding. The business judgment rule and subsequent remedial measures rules, for example, make a great deal of sense as a response to hindsight bias. ${ }^{237}$ As for the law and psychology tradition, a close look at the legal system's response to the bias suggests that the law is wellequipped to address the cognitive limitations of judges and juries. Although an understanding of cognitive biases may reveal patterns in the case law, not every bias needs a new reform. The law might have figured it out all on its own.

${ }^{20}$ FRCP 11(b) 1983 Amendments.

${ }^{24}$ See Robert G. Bone, Modeling Frivolous Suits, 145 U Pa L Rev 519, 529-33 (1997).

${ }^{205}$ FRCP 11(b) 1983 Amendments.

${ }^{206}$ FRCP 11(b) 1993 Amendments.

${ }^{207} \mathrm{Law}$ and economics scholars have theories explaining each of these. These rest largely on the possibility of errors or judicial incompetence relative to corporate managers. However, a large part of judicial incompetence is not fear of random error but systematic biases, such as the hindsight bias. 


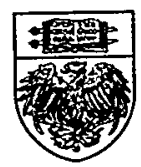

